\title{
Mitochondrial Dysfunction in Parkinson's Disease: Focus on Mitochondrial DNA
}

\author{
Olga Buneeva, Valerii Fedchenko, Arthur Kopylov (D) and Alexei Medvedev* \\ Institute of Biomedical Chemistry, 10 Pogodinskaya Street, 119121 Moscow, Russia; \\ olbuneeva@gmail.com (O.B.); valfed38@yandex.ru (V.F.); a.t.kopylov@gmail.com (A.K.) \\ * Correspondence: professor57@yandex.ru; Tel.: +7-495-245-0509
}

Received: 17 November 2020; Accepted: 8 December 2020; Published: 10 December 2020

\begin{abstract}
Mitochondria, the energy stations of the cell, are the only extranuclear organelles, containing their own (mitochondrial) DNA (mtDNA) and the protein synthesizing machinery. The location of mtDNA in close proximity to the oxidative phosphorylation system of the inner mitochondrial membrane, the main source of reactive oxygen species (ROS), is an important factor responsible for its much higher mutation rate than nuclear DNA. Being more vulnerable to damage than nuclear DNA, mtDNA accumulates mutations, crucial for the development of mitochondrial dysfunction playing a key role in the pathogenesis of various diseases. Good evidence exists that some mtDNA mutations are associated with increased risk of Parkinson's disease (PD), the movement disorder resulted from the degenerative loss of dopaminergic neurons of substantia nigra. Although their direct impact on mitochondrial function/dysfunction needs further investigation, results of various studies performed using cells isolated from PD patients or their mitochondria (cybrids) suggest their functional importance. Studies involving mtDNA mutator mice also demonstrated the importance of mtDNA deletions, which could also originate from abnormalities induced by mutations in nuclear encoded proteins needed for mtDNA replication (e.g., polymerase $\gamma$ ). However, proteomic studies revealed only a few mitochondrial proteins encoded by mtDNA which were downregulated in various PD models. This suggests nuclear suppression of the mitochondrial defects, which obviously involve cross-talk between nuclear and mitochondrial genomes for maintenance of mitochondrial functioning.
\end{abstract}

Keywords: Parkinson's disease; Parkinson's disease models; mitochondrial dysfunction; mitochondrial DNA; proteins encoded by mitochondrial genes; proteomics

\section{Introduction}

More than two centuries ago, James Parkinson described in his famous monograph "An Essay of the Shaking Palsy" (1817) the main clinical symptoms of one of the most widespread age-related neurodegenerative diseases now known as Parkinson's disease (PD) [1,2]. Elucidation of the pathological basis for the appearance of these symptoms (degeneration of dopaminergic neurons of substantia nigra pars compacta accompanied by striatal dopamine depletion) took more than one century after that description [1,2]. The development of various experimental models started in the second half of the last century and the genetic analysis of PD patients revealed molecular mechanisms crucial for important aspects of various forms of PD (both sporadic and familial) [1-3].

Results of numerous studies point to an important role of mitochondria and mitochondrial dysfunction in the pathogenesis of $\mathrm{PD}$, which started to be considered as a common feature or even as a cause of PD after discovery of MPTP (1-methyl-4-phenyl-1,2,3,6-tetrahydropyridine)-induced Parkinsonism [4], originating from the mitochondrial complex I inhibition and complex I deficiency recognized in substantia nigra of PD patients [5,6]. 
In addition to complex I defects found mainly in substantia nigra of aged and PD patients, deficient complex I activities have also been found in platelets, skeletal muscles [7-10], skin fibroblasts [11] from PD patients, but not in lymphocytes [10]. This suggests that the complex I defect seen in PD and aging is systemic and has "a genetic basis" [12]. The evaluation of molecular events leading to manifestation of PD revealed the involvement of mitochondrial proteins in the mechanisms of neuron damage and neurodegeneration. Being encoded by both nuclear and mitochondrial genomes, they have a significant impact on both mitochondrial function/dysfunction and also numerous interactions of mitochondria with other intracellular organelles. This review is focused on the particular role of mitochondrial DNA (mtDNA) and its changes associated with PD development and mitochondrial dysfunction.

\section{Mitochondrial DNA: Structure, Functions, Mode of Replication and Transcription of Mitochondrial Genes}

Mitochondria, the energy stations of the cell, are the only extranuclear organelles, containing their own (mitochondrial) DNA (mtDNA), originally discovered in 1963 [13,14], and the protein synthesizing machinery $[15,16]$. The mammalian mitochondrial genome is a multicopy circular, double-stranded DNA of about 16.5 kilobases in length; it encodes two ribosomal RNAs, 22 transfer RNAs, and just 13 protein subunits of the electron transport chain [17-20] (Table 1, Figure 1).

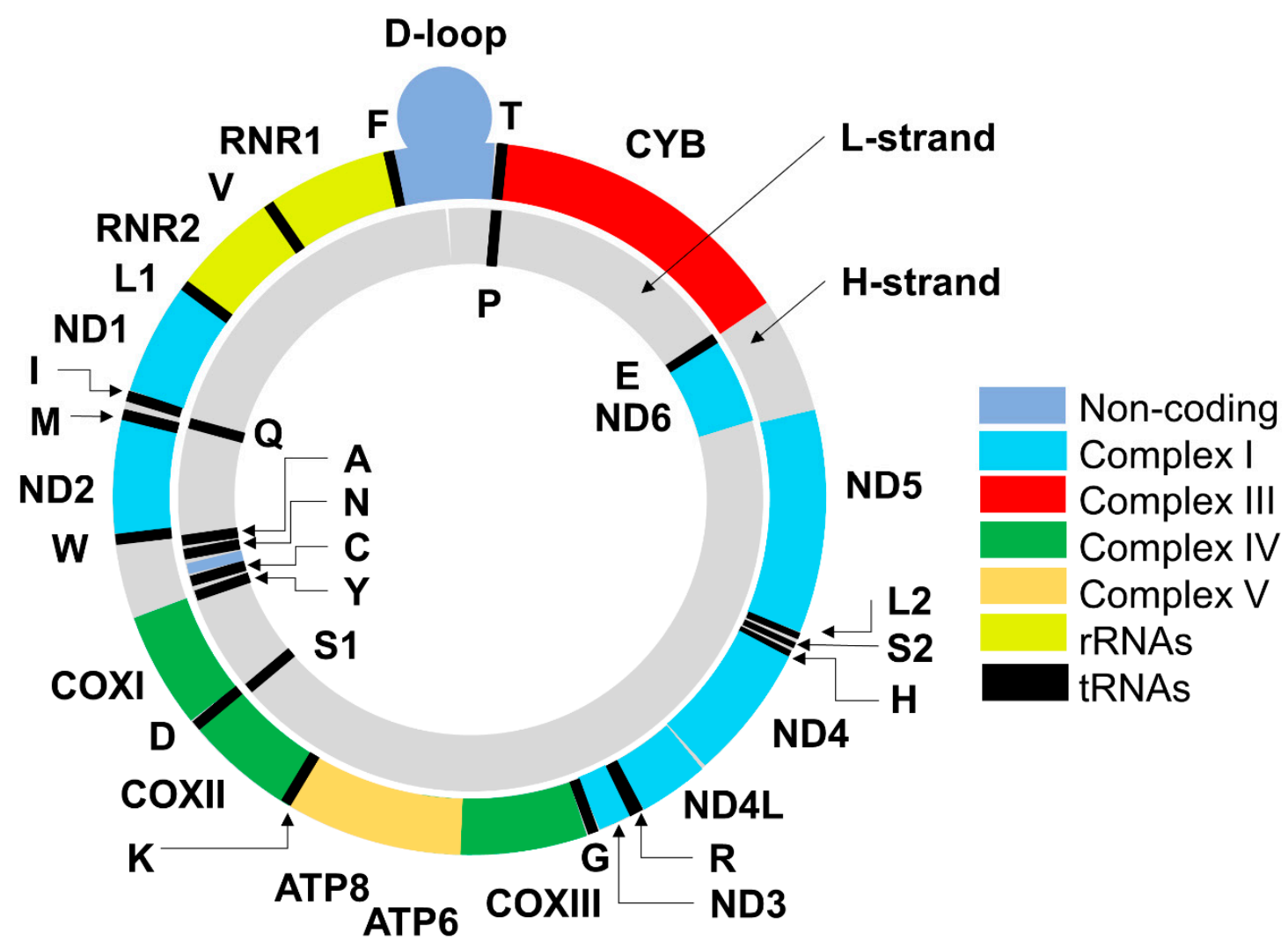

Figure 1. The scheme of the circular, double-stranded human mtDNA. The outer circle denotes the heavy $(\mathrm{H})$ strand of the mtDNA and the inner circle denotes the light $(\mathrm{L})$ strand. Colors denote genes encoding protein subunits of complexes I-V, ribosomal RNAs, transfer RNA (tRNAs designated using single-letter amino acid abbreviations), and a non-coding region (D-loop). Genes encoding protein subunits correspond to symbols of these subunits shown in Table 1. Origins of heavy and light strand replications are not shown. 
Table 1. Involvement of mtDNA in coding of components of mitochondrial complexes.

\begin{tabular}{cccc}
\hline Complexes [21-25] & Catalytic Activity (EC) & $\begin{array}{c}\text { Total Number } \\
\text { of Subunits }\end{array}$ & $\begin{array}{c}\text { Subunits Encoded by the } \\
\text { Mitochondrial Genome }\end{array}$ \\
\hline Complex I & $\begin{array}{c}\text { NADH:ubiquinone reductase } \\
\text { (EC 7.1.1.2) }\end{array}$ & 44 & $\begin{array}{c}\text { ND1, ND2, ND3, ND4, ND4L, } \\
\text { ND5, ND6 }\end{array}$ \\
\hline Complex II & $\begin{array}{c}\text { Succinate dehydrogenase } \\
\text { (EC 1.3.5.1) }\end{array}$ & 4 & 0 \\
\hline Complex III & $\begin{array}{c}\text { Ubiquinol—cytochrome-c reductase } \\
\text { (EC 7.1.1.8) }\end{array}$ & 11 & 1 (CYB) \\
\hline Complex IV & Cytochrome $c$ oxidase (EC 7.1.1.9) & 13 & COXI, COXII, COXIII \\
\hline Complex V & $\begin{array}{c}\text { ATP synthase (H }{ }^{+} \text {-transporting } \\
\text { two-sector ATPase; EC 7.1.2.2) }\end{array}$ & 14 & ATP6, ATP8 \\
\hline
\end{tabular}

MtDNA is maternally inherited. Many researchers are convinced that paternal mtDNA does not enter into the fertilized oocyte during fertilization [26,27], others suggest that sperm mitochondria are selectively targeted for degradation after fertilization [28-30]. In any case, the dogma that in humans mtDNA is maternally inherited, is used in genetic consultations [31]. The healthy cell contains several thousand mtDNAs, each of which has an identical nucleotide sequence (homoplasmy). Aging and diseases associated with mitochondrial dysfunction are characterized by the accumulation of somatic mutations and coexistence of wild type and mutant mtDNAs (heteroplasmy) and there is a correlation between the percent of mutant mtDNAs and manifestation of the disease [32].

The light $(\mathrm{L})$ and heavy $(\mathrm{H})$ strands of mtDNA differ in their base composition [33]: The L-strand is rich in cytosines, while the $\mathrm{H}$-strand is rich in guanines. The L-strand contains eight genes of tRNA and the gene of NADH-ubiquinone oxidoreductase chain 6 protein (ND6). Twenty eight other genes are located on the H-strand. They encode 14 tRNAs, two rRNAs (12S and 16S rRNA), and 12 polypeptides involved in electron transport and oxidative phosphorylation: Six subunits of the NADH-ubiquinone oxidoreductase complex (ND1, ND2, ND3, ND4, ND4L, ND5), one subunit (cytochrome $b$; CYB) of the cytochrome $b c_{1}$ complex, three subunits of the cytochrome $c$ oxidase complex (COXI, COXII, COXIII), and two subunits of the ATP synthase complex (ATP 6 and ATP8) (Figure 1).

MtDNA contains a noncoding region also known as the control region where promoters for polycistronic transcription (one for each mtDNA strand) are localized: The light strand promoter (LSP) and the heavy strand promoter (HSP) [34,35]. The control region also contains the origin for heavy strand DNA replication $(\mathrm{OH})$, while the origin for light strand replication $(\mathrm{OL})$ is located in the coding region, within a tRNA cluster $[34,36]$. The human and mammalian mitochondrial genome has its specific features different from the universal genetic code. Human and mammalian mtDNA contains 64 codons and four of them are STOP codons. Codon AUA of human mitochondria encodes methionine rather than leucine in the standard code. Arginine codons AGA and AGG are STOP codons in mtDNA. UGA, one of the three STOP codons of the standard code, encodes tryptophane in mtDNA. In addition, a single tRNA molecule of mtDNA can identify all codons of a four-codon family. This explains, why only 22 tRNAs are sufficient for identifying all the 64 codons, whereas generally there should be not less than 32 tRNAs [37]. Another feature typical of mtDNA is the high mutation frequency, which may be explained by the effects of reactive oxygen species (ROS) attributed to the proximity of the mitochondrial electron transport chain.

A short three-strand structure of mtDNA, known as the D-loop ( $\mathrm{D}$ for Displacement) forms due to the DNA replication and is situated in its non-coding region. It participates in the regulation of mtDNA replication and transcription, which involves mitochondrial proteins encoded by the nuclear genome; they are synthesized outside mitochondria and then transported to these organelles. Human mtDNA is very compact and it lacks introns. Although the mitochondrial genome encodes some basic components required for mRNA translation, the process of protein biosynthesis strictly depends on the cell nucleus, as enzymes and other protein factors needed for replication, repair, transcription, 
and translation are encoded by nuclear genes. In the context of neurodegenerative disorders associated with DNA damage, this suggests the possibility of DNA damage in both nuclear DNA and mtDNA.

MtDNA is located in the mitochondrial matrix as the nucleoprotein complexes, nucleoids $[38,39]$. The macromolecular structure of the nucleoid includes a central zone containing mtDNA and proteins needed for replication and transcription, and a peripheral zone, formed by factors involved in the association with mitochondrial ribosome, communication, and signaling with other subcellular compartments [38]. Proteomic studies employing various approaches, including nucleoid cross-linking, immunoprecipitation of known nucleoid proteins, and proximity-based labeling methods, revealed a representative group of mtDNA binding proteins [40-47]. Despite significant variations in the number of identified mtDNA binding proteins and critical evaluation of the methodical approaches used by different groups (e.g., $[39,46])$, these results indicate a rather tight association of nucleoids with the inner mitochondrial membrane, where the major sources of reactive oxygen species (ROS) are located. Indeed, electron microscopy studies have shown that nucleoids interact with the inner mitochondrial membrane [48]. Very recent electron microscopy data suggest that the mitochondrial inner membrane protein complex MICOS (mitochondrial cristae organizing system) links nucleoids to the Miro1 protein (mitochondrial Rho GTPase 1) for their active transportation to the peripheral zone of the cell [49]. This obviously explains detection (as contaminants) of NADH dehydrogenase subunits (complex I) and other proteins such as ATP synthase subunits, adenine nucleotide translocator 3, voltage-dependent anion-selective channel protein 3 (VDAC3), etc. (e.g., [42]). Since the mitochondrial nucleoid lacks a membrane, it is considered as a nucleoprotein complex [46]. Recently, a group of mitochondrial histones has been identified [43], however, their anchoring to the outer mitochondrial membrane [11] indicates that they are not involved in the interaction with mtDNA. Therefore, although the mtDNA package into nucleoids provides some protection of the mitochondrial genome, it is highly vulnerable to various damaging effects.

Studies based on electron microscopy and two-dimensional electrophoresis data revealed specific features of mammalian mtDNA replication. Three different models were suggested to explain these data. According to the strand displacement model, mtDNA replication is unidirectional, asymmetric, and asynchronous [50-53]. It begins in the origin of replication of heavy strand $(\mathrm{OH})$ and while the synthesis of a new $\mathrm{H}$ strand takes place, the parental $\mathrm{H}$-strand is covered with a single strand binding (SSB) protein. When the replication fork reaches OL, DNA forms a stem-loop structure, thus preventing SSB binding in this region. Then, RNA-polymerase POLRMT synthesizes a primer of about 25 nucleotides in length at the single strand region of the loop, and DNA polymerase gamma (POLG) continues the DNA synthesis. According to the strand-coupled model, the mtDNA replication initiates bidirectionally from a broad region of several kilobases, including the gene-encoding region of mtDNA (Ori z) [36]. The OH region functions as a replication fork barrier. The synthesis of the leading and the lagging strands (both composed of DNA) proceeds synchronously. However, molecular mechanisms responsible for this type of replication have not been characterized [34]. The mtDNA replication model RITOLS (RNA incorporated throughout the lagging strand) explains the experimental data of complementary RNA molecules discovered only in the L strand of DNA. Later, this model was complemented and renamed as a bootlace model (or bootlace strand-asynchronous replication). According to this model, RNA transcripts synthesized on the lagging strand are incorporated in the intermediates of replication, as the replication fork moves forward, and then these transcripts are replaced by the DNA lagging strand. The bootlace strand-asynchronous replication model suggests that replication initiates with the synthesis of the $\mathrm{H}$ strand at one of two sites, $\mathrm{OH}$ or Ori-b. The leading strand (H strand) synthesis proceeds unidirectionally with the simultaneous incorporation of RNA fragments into the lagging strand. The RNA lagging strand induces hybridization of mitochondrial transcripts to the parental $\mathrm{H}$ strand. The initiation of the synthesis of the lagging L strand can begin at several origins, not exclusively at OL. It proceeds unidirectionally, while RNA lagging strands are gradually removed. A lack of consensus on a common mechanism suggests the existence of several modes of the mtDNA replication. By analogy with the replication-transcription switch in human mitochondria [54], it is reasonable to 
suggest that there are regulatory factors switching these replication modes in dependence of various cell conditions.

Mitochondrial transcription and subsequent RNA processing are carried out by specialized nuclear-encoded proteins. The transcription of human mitochondrial genes involves DNA-dependent RNA polymerase POLRMT [55], which interacts with mitochondrial transcription factor A (TFAM) and mitochondrial transcription factor B2 (TFB2M). TFAM is a DNA-binding protein, which plays an important role not only in transcription activation, but also in mtDNA package within the nucleoid [46]. TFB2M is essential for promoter melting during the initiation of transcription [56]. Although only these two transcription factors are needed for transcription of the mitochondrial genes in vitro [57], animal experiments performed using manipulations with the recently discovered mitochondrial transcription elongation factor (TEFM) suggest its role in the regulation of both transcription elongation and RNA processing [58]. Transcription from the heavy (HSP) and light (LSP) strand promoters yields long polycistronic transcripts. Endonuclease excision of mitochondrial tRNAs separating coding sequences of mitochondrial rRNAs and protein coding sequences in the polycistronic transcripts is accompanied by the release of all types of mitochondrial RNAs (tRNAs, rRNA, and mRNA) [17,55]. After excision from the primary transcript, almost all mRNAs (except MT-ND6 mRNA, the only protein-coding transcript encoded on the light strand), undergo 3' polyadenylation. Polyadenylation of mitochondrial mRNAs is carried out by poly(A) RNA polymerase [59-61]. The stability of HSP-derived mitochondrial transcripts is controlled by the Leucine-rich pentatricopeptide repeat motif-containing protein (LRPPRC), which is necessary for polyadenylation $[62,63]$. The absence of LRPPRC has a significant impact on the steady-state levels of mRNAs but not rRNAs and tRNAs, and LRPPRC knockout mice are characterized by a loss in HSP-derived transcripts, loss of poly(A) tails, and a severe translational defect $[62,63]$.

\section{MtDNA Oxidation and Repair Mechanisms}

Mitochondrial dysfunction can be induced by mtDNA damage including point mutations, large-scale deletions, and oxidation [64-67]. Convincing evidence exists that under conditions of oxidative stress mtDNA damage is more extensive and persists longer than damage of nuclear DNA [68]. MtDNA is especially vulnerable to oxidative damage, due to the nucleoid location in close proximity to the inner mitochondrial membrane where the oxidative phosphorylation (OXPHOS), the major source of cell reactive oxygen species (ROS) occurs [66-68]. In addition, mitochondria are highly enriched in iron [69], which favors the formation of aggressive ${ }^{\bullet} \mathrm{OH}$ radical, preferentially reacting with intramitochondrial proteins and mtDNA due to its short half-life [70].

All the nitrogenous bases of DNA adenine, guanine, cytosine, and thymine and their corresponding deoxynucleosides are highly susceptible to oxidative damage $[66,67]$. Although various oxidized base adducts can be potentially formed during the ROS attack on the DNA [71], guanine is the most readily oxidizable base $[66,67]$. In the context of DNA oxidation, 8-oxo-guanine (8-oxoG) is the most studied form of oxidized DNA bases. Cell exposure to hydrogen peroxide is accompanied by a continuous accumulation of 8-oxoG both in nuclear DNA and mtDNA [72]. Such point lesions may be repaired by the base excision repair (BER) system [73]. BER represents the primary nuclear and mitochondrial repair pathway for oxidative DNA damage. It is initiated by DNA glycosylase, which is responsible for recognition and removal of the damaged base; the resultant abasic site is then processed by a short-patch repair or long-patch repair employing different proteins to complete BER [73]. Oxidized bases are generally removed by so-called bifunctional DNA glycosylases. In the context of mtDNA, 8-oxoguanine DNA glycosylase (OGG1) is especially important. It has two isoforms, one of which is located in the nucleus and mitochondria, while the other one is located in the mitochondria [74]. Hepatic mitDNA isolated from Ogg1-null mutant mice had a much higher (more than 20-fold) level of 8-oxoG than wild-type C57Bl/6J mice [75]. This points to the very important role of this enzyme for 8-oxoG elimination. Another enzyme that suppresses accumulation of 8-oxoG both in nuclear and mitochondrial DNA is MTH1 (MutT homolog protein 1). This oxidized purine 
nucleoside triphosphatase can hydrolyze oxidized purine nucleoside triphosphates (8-oxo-dGTP, 2-hyrdoxy-dATP) to the corresponding monophosphates [66,72]. MTH1-null mice were characterized by a higher accumulation of 8-oxoG in mtDNA but not in nuclear DNA. This was accompanied by a more significant decrease in tyrosine hydroxylase and dopamine transporter immunoreactivities than in wild-type mice $[66,72,76]$. Abasic sites, formed in mtDNA due to a spontaneous base loss or induced by ROS, are also harmful particularly in mitochondria due to the decreased activity of mitochondrial DNA polymerase [77]. Generation of a mouse model with a mutated version of the uracil N-glycosylase (UNG) DNA repair enzyme, which removed thymine from the mitochondrial genome, revealed highly elevated levels of apyrimidinic sites in hippocampal mtDNA [78].

Studies performed using neuroblastoma SH-SY5Y cells treated with hydrogen peroxide $(100-1000 \mu \mathrm{M})$ revealed that at lower $\mathrm{H}_{2} \mathrm{O}_{2}$ concentrations the non-coding regulatory D-loop was more vulnerable to $\mathrm{H}_{2} \mathrm{O}_{2}$ induced mtDNA damage than the three coding regions tested. At a higher concentration of $\mathrm{H}_{2} \mathrm{O}_{2}(750-1000 \mu \mathrm{M})$ the difference in the lesion rates disappeared [79]. Since replication of mtDNA starts in the D-loop region [34-36] its higher sensitivity to $\mathrm{ROS}\left(\mathrm{H}_{2} \mathrm{O}_{2}\right)$ suggests different rates of mtDNA damage and copy number recovery. Indeed, the initial hydrogen-peroxide mtDNA damage almost reversed after $48 \mathrm{~h}$, while the mtDNA copy number was reduced to 50\% in the SH-SY5Y cells [79].

\section{Age-Related Changes in mtDNA}

Generally, age-associated oxidation of mtDNA originates from an increased oxidative attack to the nucleic acids and a decreased efficacy in mtDNA repair mechanisms $[67,80,81]$. The aging brain is characterized by an increased oxidative damage of mtDNA evaluated by the formation of 8-oxoG, commonly considered as the marker of oxidative DNA damage [80,81]. The age-related increase in 8-oxoG was found in several cerebral regions of aged human brains [82]. The extent of 8-oxoG in mtDNA was one order of magnitude higher than in nuclear DNA [82]. The same trend was also detected in brains (and hearts) of aged mice, rats, guinea pigs, and rabbits and also sheep, pigs, cows, and horses [83]. Moreover, oxidative damage of mtDNA inversely correlated with the maximum life span of these animals. This suggests the applicability of animal models for the study of PD.

The age-related increase in oxidative mtDNA damage is obviously associated with age-related impairments of the components of the mitochondrial BER machinery (OGG1, UDG, APE1, and polymerase $\gamma$ ) [84-86]. Mouse brain mtDNA repair activities demonstrated clear regiospecific differences [86]. For example, in mice mtDNA glycosylase activities were lower in hippocampal than in cortical mitochondria. Mitochondrial AP endonuclease activity increased in old animals in both brain regions, while cortical but not hippocampal mtDNA glycosylase activities declined with age [86]. In substantia nigra of neurologically healthy individuals the number of hOGG1-2a-positive neurons (stained with antibody to the mitochondria specific isoform) demonstrated an age-dependent increase [87].

The analysis of blood samples ( $n=2491$, age-range $0-60$ years) revealed a significant age-dependent increase in the mtDNA heteroplasmy [88]. These results are consistent with high levels of mtDNA deletions found in substantia nigra neurons of the aged brain [89,90]. Nevertheless, dopaminergic substantia nigra neurons of neurologically healthy individuals demonstrated an age-related increase in mtDNA copy number and maintained the pool of wild-type mtDNA population despite accumulated deletions [91].

Therefore, although it is reasonable to suggest that the increase in the oxidative damage of mtDNA could account for age-related accumulations of point mutations and deletions in the mitochondrial genome, there are certain concerns, whether these changes are a cause or consequence of the aging process [92]. 


\section{MtDNA Changes in Parkinson's Disease}

\subsection{MtDNA Mutations}

Although mtDNA sequencing did not reveal characteristic pathogenic mutation(s) as a PD signature [93], there was an age-dependent increase in mtDNA deletions associated with respiratory chain dysfunction detected in the dopaminergic neurons of substantia nigra [89,90]. Dopaminergic neurons with normal cytochrome oxidase activity were characterized by very high levels of mtDNA deletions. The level of somatic mtDNA deletions was slightly higher in substantia nigra of PD patients than in age-matched controls. Since mtDNA deletions were not seen in other types of neurons in aged brains [89,90], it was suggested that they were specific for substantia nigra [89].

The other study also revealed that the number and variety of mtDNA deletions/rearrangements were selectively increased in postmortem samples of substantia nigra from PD patients as compared to both patients with other types of neurodegenerative pathology (movement disorders and Alzheimer's disease) and aged controls [94]. Other brain regions of PD patients also demonstrated increased mtDNA deletions/rearrangements, thus indicating that in these patients mitochondrial dysfunction was not limited to the substantia nigra [94]. This suggests that the accumulation of mtDNA deletions/rearrangements could be not only a specific sign of PD but also an important factor responsible for the development of mitochondrial dysfunction and neurodegeneration in PD. Table 2 lists some mutations in mtDNA associated with PD.

Table 2. Mitochondrial DNA (mtDNA) mutations associated with Parkinson's disease (PD).

\begin{tabular}{|c|c|c|c|c|}
\hline Gene Encoding & $\begin{array}{c}\text { Nucleotide } \\
\text { Position in } \\
\text { mtDNA Genome }\end{array}$ & $\begin{array}{l}\text { Mutation } \\
\text { Location }\end{array}$ & Detected Effect & References \\
\hline $\begin{array}{l}\text { tRNA threonine } \\
\text { tRNA (Thr) }\end{array}$ & $15888 . .15953$ & $\begin{array}{c}\text { nt.15927 and } \\
\text { nt.15928 }\end{array}$ & $\begin{array}{l}\text { Frequent point } \\
\text { mutations }\end{array}$ & [95] \\
\hline $\begin{array}{l}\text { tRNA glutamine } \\
\text { tRNA (Gln) }\end{array}$ & $4329 . .4400$ & nt.A4336G & $\begin{array}{l}\text { Loss of the HpaII site, } \\
\text { increased frequency in } \\
\text { PD-women } \\
\text { The activity of complex I } \\
\text { may be decreased }\end{array}$ & [95-100] \\
\hline $\begin{array}{l}\text { tRNA leucine } 1 \\
\text { (UUA/G) tRNA } \\
\text { (Leu) }\end{array}$ & $3230 . .3304$ & nt.G3243A & $\begin{array}{c}\text { point mutation, } \\
\text { heteroplasmic state }\end{array}$ & [101] \\
\hline $\begin{array}{l}\text { tRNA lysine } \\
\text { tRNA (Lys) }\end{array}$ & $8295 . .8364$ & nt.A8344G & point mutation & [102] \\
\hline $\begin{array}{l}\text { 12S ribosomal RNA } \\
\text { (RNR1) }\end{array}$ & $648 . .1601$ & $\begin{array}{l}\text { nt. 956-965, } \\
\text { nt. T1095C }\end{array}$ & $\begin{array}{l}\text { 5-nucleotide insertion, } \\
\text { point mutation }\end{array}$ & {$[103,104]$} \\
\hline 16S RNA (RNR2) & $1671 . .3229$ & $\begin{array}{l}\text { nt.T2158C } \\
\text { nt.3196 }\end{array}$ & $\begin{array}{l}\text { associated with reduced } \\
\text { risk of PD } \\
\text { heteroplasmic } 16 \mathrm{~S} \text { rRNA } \\
\text { variant }\end{array}$ & {$[103,105]$} \\
\hline $\begin{array}{c}\text { NADH } \\
\text { dehydrogenase, } \\
\text { subunit } 1 \text { (ND1) }\end{array}$ & $3307 . .4262$ & $\begin{array}{l}\text { nt.A3397G } \\
\text { nt.T4216C }\end{array}$ & polymorphism & {$[101,106]$} \\
\hline $\begin{array}{c}\text { NADH } \\
\text { dehydrogenase, } \\
\text { subunit } 2 \text { (ND2) }\end{array}$ & $4470 . .5511$ & $\begin{array}{c}\text { nt.G5460A } \\
\text { nt.C5178A } \\
\text { nt.4977 } \\
\text { p.A5T, p.A5V, } \\
\text { p.M187T, p.M187I, } \\
\text { p.I239M, p.I239H }\end{array}$ & $\begin{array}{l}\text { point mutation } \\
\text { point mutation } \\
\text { common deletion } \\
\text { amino acid substitutions }\end{array}$ & $\begin{array}{c}{[98]} \\
{[107,108]} \\
{[109,110]} \\
{[111-113]}\end{array}$ \\
\hline
\end{tabular}


Table 2. Cont.

\begin{tabular}{|c|c|c|c|c|}
\hline Gene Encoding & $\begin{array}{c}\text { Nucleotide } \\
\text { Position in } \\
\text { mtDNA Genome }\end{array}$ & $\begin{array}{c}\text { Mutation } \\
\text { Location }\end{array}$ & Detected Effect & References \\
\hline $\begin{array}{c}\text { Cytochrome } c \\
\text { oxidase subunit I }\end{array}$ & $5904 . .7445$ & nt.G6930A & $\begin{array}{c}\text { Point mutation, causing } \\
\text { enhanced ROS } \\
\text { production }^{\text {a }}\end{array}$ & [114-116] \\
\hline $\begin{array}{c}\text { NADH } \\
\text { dehydrogenase, } \\
\text { subunit } 3 \text { (ND3) }\end{array}$ & 10059..10404 & nt.A10398G & $\begin{array}{l}\text { point mutation } \\
\text { Haplogroup I, J, or K had } \\
\text { a slightly decreased risk } \\
\text { of PD but an increased } \\
\text { risk of PDD Protective } \\
\text { effect for women }\end{array}$ & {$[99,117,118]$} \\
\hline $\begin{array}{c}\text { NADH } \\
\text { dehydrogenase, } \\
\text { subunit 4L (ND4L) }\end{array}$ & 10470..10766 & p.L77F & amino acid substitution & [111] \\
\hline $\begin{array}{c}\text { NADH } \\
\text { dehydrogenase, } \\
\text { subunit } 4 \text { (ND4) }\end{array}$ & 10760..12137 & nt.A11251G & $\begin{array}{l}\text { point mutation } \\
\text { associated with reduced } \\
\text { risk of PD }\end{array}$ & [105] \\
\hline $\begin{array}{c}\text { NADH } \\
\text { dehydrogenase, } \\
\text { subunit 5 (ND5) }\end{array}$ & 12337..14148 & $\begin{array}{l}\text { p.E145G, pE145V, } \\
\text { p.E145D } \\
\text { p.124-145 }\end{array}$ & $\begin{array}{l}\text { amino acid substitution, } \\
\text { deletion of } 30 \mathrm{nts}\end{array}$ & $\begin{array}{l}{[111]} \\
{[119]}\end{array}$ \\
\hline $\begin{array}{l}\text { 12S ribosomal RNA } \\
\text { (RNR1) }\end{array}$ & $648 . .1601$ & $\begin{array}{l}\text { nt. 956-965, } \\
\text { nt. T1095C }\end{array}$ & $\begin{array}{l}\text { 5-nucleotide insertion } \\
\text { point mutation }\end{array}$ & {$[103,104]$} \\
\hline $\begin{array}{l}\text { 16S ribosomal RNA } \\
\text { (RNR2) }\end{array}$ & $1671 . .3229$ & $\begin{array}{l}\text { nt.T2158C } \\
\text { nt.3196 }\end{array}$ & $\begin{array}{l}\text { associated with reduced } \\
\text { risk of PD } \\
\text { heteroplasmic } 16 \mathrm{~S} \text { rRNA } \\
\text { variant }\end{array}$ & $\begin{array}{l}{[105]} \\
{[103]}\end{array}$ \\
\hline $\begin{array}{c}\text { NADH } \\
\text { dehydrogenase, } \\
\text { subunit 6 (ND6) }\end{array}$ & $14149 . .14673$ & nt.T14487C & $\begin{array}{l}\text { Point mutation causing } \\
\text { free radical damage } \\
\text { of cells } \mathrm{b}\end{array}$ & {$[120,121]$} \\
\hline mtDNA & $\begin{array}{c}\text { complete genome } \\
16569\end{array}$ & & heteroplasmy & [122] \\
\hline mtDNA & $\begin{array}{l}\text { complete genome } \\
16569 \mathrm{bp}\end{array}$ & $\begin{array}{l}\text { Transversions } \mathrm{G}: \mathrm{C} \\
\rightarrow \mathrm{T}: \mathrm{A} \text { and } \mathrm{T}: \mathrm{A} \rightarrow \\
\mathrm{G}: \mathrm{C} \text { in point } \\
\text { mutations }\end{array}$ & $\begin{array}{l}\text { all point mutations } \\
\text { increase with age in the } \\
\text { frontal cortex (FCtx) }\end{array}$ & [123] \\
\hline
\end{tabular}

${ }^{a}$ Cybrids containing mtDNA carrying the stop-codon mutation or nonsense mutation; ${ }^{\mathrm{b}}$ cybrids containing mtDNA carrying mutation in the NADH dehydrogenase subunit (see Section 5.4 of this review). PDD is Parkinson's disease dementia.

Data in Table 2 show that not all mutations recognized in the mitochondrial genome are functionally linked to mitochondrial dysfunction and results of population genetic studies require further functional studies.

\subsection{Substantia Nigra Samples from PD Patients}

The analysis of 11 brain regions of postmortem brain samples from PD patients and controls revealed a selective increase in 8-oxoG levels in substantia nigra [124]. Since authors were limited in the biological materials they investigated total cell DNA. However, the accumulation of 8-oxoG was later demonstrated in mtDNA of nigrostriatal dopaminergic neurons of PD patients [66]. Substantia nigra neurons from aged individuals and PD patients also had high levels of deletions in mtDNA [89]. These mtDNA lesions were associated with respiratory chain deficiency.

Using ultradeep sequencing of mtDNA it has been shown that individual dopaminergic neurons of substantia nigra from PD patients contained a higher pool of mtDNA deletions than it was previously reported [125]. Each substantia nigra neuron contained more than 30 distinct $\mathrm{mtDNA}$ deletions and 
most of these deletions were found to be present in very low frequencies and were located in areas of perfect or interrupted homology [125]. In contrast to neurons of control individuals demonstrating an age-related increase in the mtDNA copy number and maintenance of wild-type mtDNA population, corresponding neurons from PD patients were characterized by depletion of the wild-type mtDNA population [91]. However, the neuronal mtDNA point mutational load did not increase in PD patients [91]. The other study revealed increased expression of the mitochondrial isoenzyme, OGG1, involved in mtDNA repair, in substantia nigra neurons of PD patients [87].

\subsection{Other Cells from PD Patients}

In addition to brain samples obtained post mortem, changes in mtDNA have been also investigated using biopsy samples from PD patients. The study of mtDNA replication and transcription in skin fibroblasts from patients with familial LRRK2-associated and idiopathic PD has shown that these cells obtained from both groups of patients are characterized by similar dysfunctions of the mtDNA replication and transcription machinery [126]. These included the accumulation of 7S mtDNA, low mtDNA replication, high heavy strand transcription, and low cell-free mtDNA release [126]. The latter (cell free mtDNA release) is currently considered as an active physiological process regulated by metabolic stress rather than a hallmark of cell lysis [126]. The altered level in 7S DNA, which plays a role in the switch between replication and transcription of mtDNA [54], is considered as a basic mechanism in the pathogenesis of idiopathic and monogenic LRRK2-associated PD.

\subsection{Studies Using Cytoplasmic Hybrid (Cybrid) Cell Lines}

In the context of studies aimed at elucidation of the role of mtDNA in mitochondrial dysfunction and pathogenesis of PD, the cytoplasmic hybrid studies performed using mitochondria from cells obtained from PD patients made a significant contribution $[12,127,128]$. Cybrid cells are generated by mixing contents of a non-nucleated cell with a nucleated cell. The nucleated cell is usually a tumor cell with depleted mtDNA (known as a $\varrho_{0}$ cell) and the platelet usually represents a source of the non-nucleated cell containing functionally competent mitochondria [129]. Since cybrids share the same nuclear genetic background, the differences in structure-functional parameters of the generated cybrid cells containing mtDNA from various sources are obviously originated from the differences in their mtDNA. Table 3 summarizes results obtained using such systems.

Table 3. The role of mtDNA alterations in the mitochondrial dysfunction and extramitochondrial processes evaluated in PD cybrid cells.

\begin{tabular}{|c|c|c|c|c|}
\hline $\begin{array}{c}\text { Source of PD } \\
\text { mtDNA }\end{array}$ & $\begin{array}{l}\text { Cell Line Used to } \\
\text { Generate Cybrids }\end{array}$ & $\begin{array}{l}\text { Mitochondrial } \\
\text { Changes }\end{array}$ & $\begin{array}{c}\text { Extramitochondrial } \\
\text { Changes }\end{array}$ & Reference \\
\hline $\begin{array}{l}\text { Platelets from } \\
\text { sporadic PD } \\
\text { patients }\end{array}$ & $\begin{array}{c}\text { SHSY5Y } \\
\text { neuroblastoma }\end{array}$ & $\begin{array}{l}\text { Decreased complex I } \\
\text { activity and increased } \\
\text { ROS production }\end{array}$ & $\begin{array}{l}\text { Increased susceptibility } \\
\text { MPP-induced } \\
\text { programmed cell death }\end{array}$ & [130] \\
\hline $\begin{array}{l}\text { PD patients with } \\
\text { low platelet } \\
\text { complex I activity }\end{array}$ & $\begin{array}{l}\text { A549 lung } \\
\text { adenocarcinoma }\end{array}$ & $\begin{array}{l}\text { combined complex I and } \\
\text { IV deficiencies }\end{array}$ & & [131] \\
\hline $\begin{array}{l}\text { PD patients with } \\
\text { reduced platelet } \\
\text { complex I activity }\end{array}$ & $\begin{array}{c}\text { NT2 } \\
\text { teratocarcinoma } \\
\text { cells }\end{array}$ & $\begin{array}{c}\text { Decreased Complex I-IV } \\
\text { activities }\end{array}$ & $\begin{array}{l}\text { Increased LDH release, } \\
\text { increased caspase- } 3 \\
\text { activity, increased } \\
\mathrm{MPP}^{+} \text {-induced activation } \\
\text { of caspase- } 9 \text { and caspase- } 3\end{array}$ & [132] \\
\hline $\begin{array}{l}\text { Platelets from } \\
\text { sporadic PD } \\
\text { patients }\end{array}$ & $\begin{array}{l}\mathrm{NT} 2 \\
\text { teratocarcinoma } \\
\text { cells }\end{array}$ & $\begin{array}{l}\text { Decreased Complex I } \\
\text { activity and ATP level }\end{array}$ & $\begin{array}{l}\text { Higher ROS production, } \\
\text { Increased number of } \\
\text { protein carbonyl groups, } \\
\text { microtubule alteration, } \\
\alpha \text {-synuclein } \\
\text { oligomerization }\end{array}$ & [133] \\
\hline
\end{tabular}


Table 3. Cont.

\begin{tabular}{|c|c|c|c|c|}
\hline $\begin{array}{l}\text { Source of PD } \\
\text { mtDNA }\end{array}$ & $\begin{array}{l}\text { Cell Line Used to } \\
\text { Generate Cybrids }\end{array}$ & $\begin{array}{l}\text { Mitochondrial } \\
\text { Changes }\end{array}$ & $\begin{array}{l}\text { Extramitochondrial } \\
\text { Changes }\end{array}$ & Reference \\
\hline $\begin{array}{l}\text { Platelets from PD } \\
\text { patients without } \\
\text { any nuclear } \\
\text { DNA mutation }\end{array}$ & $\begin{array}{c}\text { NT2 } \\
\text { teratocarcinoma } \\
\text { cells }\end{array}$ & & $\begin{array}{c}\text { Increased protein } \\
\text { ubiquitination, } \\
\text { microtubule } \\
\text { depolymerization, and } \\
\alpha \text {-synuclein } \\
\text { oligomerization }\end{array}$ & [134] \\
\hline $\begin{array}{l}\text { Platelets from } \\
\text { PD patients }\end{array}$ & $\begin{array}{c}\text { NT2 } \\
\text { teratocarcinoma } \\
\text { cells }\end{array}$ & $\begin{array}{l}\text { Decreased mitochondrial } \\
\text { calcium }\end{array}$ & $\begin{array}{c}\text { Increased cytosolic } \\
\text { calcium, increased calpain } \\
\text { expression, and activation }\end{array}$ & [135] \\
\hline $\begin{array}{l}\text { PD patients with } \\
\text { reduced platelet } \\
\text { complex I activity }\end{array}$ & $\begin{array}{c}\text { NT2 } \\
\text { teratocarcinoma } \\
\text { cells }\end{array}$ & $\begin{array}{l}\text { Decreased Complex I } \\
\text { activity, lower ATP, } \\
\text { depolarized } \\
\text { mitochondria, slightly } \\
\text { increased } \\
\text { ATP-independent } \\
\text { proton leak }\end{array}$ & $\begin{array}{l}\text { Decreased levels of PGC1 } \alpha \\
\text { Decreased levels of SIRT1 } \\
\text { phosphorylation } \\
\text { Higher transcriptional } \\
\text { activity of NF-KB }\end{array}$ & [136] \\
\hline $\begin{array}{l}\text { Platelets from } \\
\text { individuals with } \\
\text { idiopathic } \\
\text { (sporadic) } \\
\text { Parkinson's disease } \\
\text { (sPD) }\end{array}$ & $\begin{array}{c}\text { SH-SY5Y } \\
\text { Neuroblastoma } \\
\text { cells }\end{array}$ & $\begin{array}{l}\text { Insignificant trend for } \\
\text { reduction of Complex I } \\
\text { respiration, unaltered } \\
\text { level of ETC subunit } \\
\text { proteins } \\
\text { mtDNA levels varied }\end{array}$ & $\begin{array}{l}\text { mtDNA levels varied and } \\
\text { correlated with expression } \\
\text { of PGC- } 1 \alpha\end{array}$ & [137] \\
\hline $\begin{array}{l}\text { Platelets from } \\
\text { Contursi kindred } \\
\text { PD subjects }\end{array}$ & $\begin{array}{c}\text { SH-SY5Y } \\
\begin{array}{c}\text { Neuroblastoma } \\
\text { cells }\end{array}\end{array}$ & $\begin{array}{l}\text { Lack of significant } \\
\text { changes in Complex I } \\
\text { and IV activities }\end{array}$ & $\begin{array}{l}\text { Increased glutathione } \\
\text { peroxidase }\end{array}$ & [138] \\
\hline $\begin{array}{l}\text { Platelets from } \\
\text { elderly PD patients }\end{array}$ & HeLa cells & $\begin{array}{l}\text { mtDNA transfer restored } \\
\text { mitochondrial } \\
\text { respiration of HeLa cells } \\
\text { No significant changes } \\
\text { were found between } \\
\text { control and PD cybrids }\end{array}$ & & [139] \\
\hline $\begin{array}{l}\text { Platelets from a } \\
\text { patient with } \\
\text { mtDNA mutation } \\
\text { T14487C mutant }\end{array}$ & $\begin{array}{l}\text { human } \\
\text { osteosarcoma } \\
\text { 143B cells }\end{array}$ & $\begin{array}{l}\text { Overproduction of ROS } \\
\text { causing increased } \\
\text { oxidation of lipids } \\
\text { and mtDNA }\end{array}$ & $\begin{array}{l}\text { Increased lipid oxidation } \\
\text { Insignificant changes in } \\
\text { catalase and SOD }\end{array}$ & $\begin{array}{l}{[121]} \\
{[120]}\end{array}$ \\
\hline $\begin{array}{c}\text { Enucleated cells } \\
\text { from patients with } \\
\text { mtDNA } \\
\text { mutationsA3243G } \\
\text { in tRNA }{ }^{\text {LeuUUR }} \\
\text { and A8344G in } \\
\text { tRNA }{ }^{\text {Lys }}\end{array}$ & $\begin{array}{c}\text { human } \\
\text { osteosarcoma cells } \\
\text { (A3243G in } \\
\text { tRNA } \text { LeuUUR }_{\text {and }} \\
\text { A8344G in } \\
\text { tRNA }^{\text {Lys }} \text { ) }\end{array}$ & $\begin{array}{l}\text { both mutations showed } \\
\text { severe deficits of } \\
\text { complexes I, III, and IV }\end{array}$ & $\begin{array}{l}\text { Increased ROS production } \\
\text { with a parallel increase in } \\
\text { the antioxidant enzyme } \\
\text { activities (SOD, catalase, } \\
\text { glutathione peroxidase) }\end{array}$ & [114] \\
\hline
\end{tabular}

It appears that certain but not all studied cybrids containing mtDNA from PD patients differ from control cybrids containing mtDNA from non PD subjects. A decrease in Complex I activity and increased generation of ROS are consistent with results obtained using various cells from PD patients (see above). Since focal respiratory chain defects initially seen in platelets of patients with other pathologies (e.g., Alzheimer's disease) or documented lesions of mtDNA (e.g., some mutations, see Table 2) have been reproduced in the cybrid cells, such cybrid cells represent an adequate model for characterization of molecular events associated with mitochondrial dysfunction. Other processes altered in cybrid cells, containing mitochondria from PD patients versus control cybrids (Table 3) reflect complex interactions, including both effects of components transferred together with mitochondria to the nucleated tumor $\varrho_{0}$ cell, as well as a functional crosstalk between mtDNA and nuclear DNA [140]. 


\section{Studies Using Animal Models of Parkinson's Disease}

\subsection{MPTP-Induced Parkinsonism}

In the context of PD models in animals, MPTP-induced Parkinsonism is one of the commonly used experimental models reproducing the main neuropathological hallmarks of this disease [2,31,66,141,142]. In Parkinsonism induced by administration of MPTP, 1-methyl-4-phenyl-1,2,3,6-tetrahydropyridine (a protoxin) undergoes catalytic conversion by monoamine oxidase B (MAO B), which is self-inactivated during this process. The resultant neurotoxin $\mathrm{MPP}^{+}$(1-methyl-4-phenylpyridinium) inhibits complex I of the respiratory chain and causes development of symptoms typical of PD [2,141,142].

A single dose administration of MTPT to mice $(30 \mathrm{mg} / \mathrm{kg}$ ) caused characteristic locomotor impairments, rapidly developed within 90-120 min [143,144]. They were accompanied by increased ubiquitination of oxidized proteins associated with brain mitochondria [144]. This points to an early involvement of mitochondria in the cell response to the administered toxin. Administration of the same dose of MPTP to mice caused accumulation of 8-oxoG in striatum and substantia nigra observed 12-24 $\mathrm{h}$ after the MPTP injection [66,72,76]. The accumulation of 8-oxoG in mtDNA induced by MPTP administration was more pronounced in MTH1-null mice defective in the MTH1 gene encoding 8-oxo-dGTPase than in wild-type mice $[66,76]$. These changes (8-oxoG accumulation in mtDNA) appeared in substantia nigra and striatum prior to loss of their neurons [76]. Interestingly, the level of 8-oxoG in nuclear DNA insignificantly differed between wild-type and MTH1-null mice [66,76].

The treatment of mice with MPTP $(10 \mathrm{mg} / \mathrm{kg}$ for 4 days with a 3-day interval after the last injection) caused mtDNA damage evaluated by quantitative PCR [145]. This damage was more pronounced in old (1-year old) than in young (22-day old) mice and substantia nigra DNA was more affected than caudate-putamen and cerebellum [145]. In vitro treatment of cells with $\mathrm{MPP}^{+}$, the toxin formed during MAO B-dependent conversion of MPTP, also caused mtDNA damage. For example, the treatment of SH-SY5Y cells with $1 \mathrm{mM} \mathrm{MPP}^{+}$increased mitochondrial 8-oxoG after $1 \mathrm{~h}$, while in the nucleus 8-oxoG accumulation was observed $2 \mathrm{~h}$ later [146].

However, despite early mtDNA damage observed within 12-24 h after MPTP administration (and development of movement disorder), proteomic analyses performed in other laboratories did not reveal significant alterations in the level of proteins encoded by mtDNA [147,148]. About two hundred genes, including genes encoding five subunits of complex I (Ndufa10, Ndufb5, Ndufs2, Ndufs7, Ndufb9) and several ATP synthase subunits responded to MPTP administration. However, the only significant change (downregulation) in the mitochondrial genome was found in the case of ATP synthase subunit 8 [147] encoded by the mitochondrial gene located on the H-strand (see Figure 1). This suggests preferential involvement of the nuclearly encoded mitochondrial proteins in the MPTP-induced changes at least within the particular protocol used: Four sequential injections of MPTP (15 mg/kg per injection) at $2 \mathrm{~h}$ intervals with bilateral removal of striatum and other brain regions (cortex, cerebellum, and the rest of the brain) 7 days after the injections [147]. We suggest that the selection of appropriate experimental protocols appears to play an important role especially if we take into consideration that the mtDNA damage and mtDNA copy number demonstrated different recoveries after the ROS-dependent treatment of cells (see the last paragraph of Section 3).

\subsection{Rotenone-Induced Parkinsonism}

The other popular toxin-based model of PD is rotenone-induced Parkinsonism. In this model, repeated systemic injections of the pesticide rotenone to rats caused the inhibition of mitochondrial complex I in the nigrostriatal dopamine system $[149,150]$ and also in the mitochondria of peripheral organs (e.g., liver, [151]). Although histopathological and other examinations of about 40 organs revealed several crucial targets (liver, bone marrow, and bone) [151], the brain rotenone treatment caused selective degeneration of the nigrostriatal dopamine system and reproduced major clinical symptoms typical of PD [149,150]. In the rotenone model of PD in rats the mtDNA damage (apurinic/apyrimidinic (abasic) sites) was detected even after a single dose administration [150], which did not cause behavioral 
symptoms of Parkinsonism [149]. This mtDNA damage was detectable in substantia nigra (but not in the cortex) and occurred before signs of nigrostriatal system degeneration.

Recently, the performed proteomic analysis using IMR-32 cells treated with retinoic acid for their differentiation into dopaminergic neuron population has shown that the treatment with rotenone affected the expression of more than 400 proteins [152]. However, the only protein encoded by mtDNA was the COXII subunit and its level insignificantly differed from the control (the rotenone/control ratio was 1.06) [152]. It would be interesting to repeat such proteomic analysis using rotenone-treated animals, exhibiting symptoms of PD.

\subsection{Polg Mutator Mice}

DNA polymerase- $\gamma$ is the principal enzyme in mtDNA replication and mtDNA proofreading. The lack of this enzyme causes early embryonic death [153], while a missense mutation causing amino acid substitution D257A only reduces the $3^{\prime}-5^{\prime}$ exonuclease activity needed for proofreading without a significant change of the mtDNA replication capacity [154,155]. The homozygous Polg ${ }^{D 257 A / D 257 A}$ mice carrying this mutation die prematurely at the age of about 12 months (41-59 weeks) due to increased random accumulations of mtDNA mutations, while wild-type mice live more than 2 years [154,155]. The knock-in mice developed an mtDNA mutator phenotype with a several fold increase in the levels of point mutations and increased amounts of deleted mtDNA. The rate of mtDNA mutations markedly differed in various tissues of the mitochondrial mutator mice [156].

In the skeletal muscle mitochondria of 11-month old Polg mutator mice, the total content of mitochondrial electron transport chain decreased by 35\% (complex I); 37\% (complex III), and by $50 \%$ (complex IV). The analysis of selected subunits revealed a significant decrease in both nuclear-encoded (NDUFA9 and NDUFS3 subunits of complex I, $29 \mathrm{kDa}$ and $48 \mathrm{kDa}$ subunits of complex III), and mitochondrial-encoded subunits (COXI subunit of Complex IV) [157]. Gene expression profiling revealed 97 differentially expressed genes with the highest upregulation of genes encoding extramitochondrial proteins (HD domain containing protein 3-9.7 fold; acetyl-CoA synthetase 6.8-fold; Cd209e gene-like protein E-4.1-fold). The most prominent downregulation was observed for alpha kinase 3 (-4.5-fold), immunoglobulin heavy locus (-4-fold), and 3-hydroxybutyrate dehydrogenase 1 (-3.6-fold) [157]. Interestingly, a similar study performed in young (3-month old) mutator mice did not reveal differentially expressed genes [157]. No changes were also observed in 8-oxodG levels in mtDNA between wild-type and mtDNA mutator mice [158].

Young (2-3 month old) Polg D257A/D257A mutator mice did not demonstrate higher neuronal vulnerability than the wild-type mice [159]. In addition, another study has shown that $D J$-1-deficient mice, Polg mutator mice, and DJ-1-deficient Polg mutator mice had intact nigrastriatal pathways [160]. Neurons and muscle cells of mtDNA mutator mice maintained a well-preserved mitochondrial respiratory chain [161]. Mitochondrial levels of hydrogen peroxide in the studied tissues (liver, kidney, heart, and skeletal muscles) were basically the same in young Polg mutator mice and wild-type mice, while in mature mtDNA mutator animals were higher in the heart and kidney [162].

Nevertheless, quantitative proteomic profiling revealed brain proteins differentially expressed in the Polg mutator mice as compared with the wild-type mice [163]. At least several mitochondrial respiratory chain subunits were significantly decreased and these included cytochrome $c$-oxidase subunit 2 (COXII) encoded by the mitochondrial genome. However, RNA-Seq performed using mRNA extracted from the same cohort male aged mice used in the proteomic experiment revealed 18 (of 28100 identified) genes expressed differently in Polg mutator mice as compared with the wild-type mice and they did not overlap with proteomic data [163]. This points to the lack of direct interrelationship between proofreading defects during mtDNA replication and the development of age-related neurodegenerative pathology such as PD. 


\section{Conclusions}

Convincing evidence exists that mtDNA is involved in the mitochondrial dysfunction in Parkinson's disease. However, it still remains unclear, whether numerous mtDNA damages (oxidation, deletions, mutations, and heteroplasmy) described in the literature are the cause or consequence of PD [12,164,165]. On the one hand, the analysis of human (including postmortem brain) tissue samples demonstrating various types of mtDNA damage suggests that the recognized changes may be attributed to the final outcome of the disease. On the other hand, results of animal studies, simulating crucial stages of PD, indicate that at least mtDNA oxidation/damage, seen for example in the MPTP mouse model (see Section 7 of this review), may be referred to as one of the early events preceding the appearance of detectable changes in the levels of differentially expressed proteins. However, quantitative proteomic studies have shown that the level of mitochondrial proteins encoded by mtDNA remains basically unchanged [147,148,152]. This is a common feature found not only in the rodent but also in the MPTP-monkey model of PD. In the latter case, the proteomic analysis of postmortem brains from both Macaca mulatta monkeys (the rhesus monkeys) demonstrating severe parkinsonian symptoms and asymptomatic animals poorly responding to MPTP administration revealed 86 differentially expressed proteins as compared with untreated monkeys [166]. However, none of these proteins were encoded by mtDNA. The only protein related to mitochondria was the ATP synthase subunit alpha encoded by nuclear DNA [166].

Such mitochondrial resistance may be attributed to different roles of particular subunits encoded by mtDNA in the assembly and functioning of mitochondrial complexes (e.g., [167]). For example, mutations in mitochondrial genes encoding ND1 and ND3 subunits of complex I cause MELAS (mitochondrial encephalopathy, lactic acidosis, and stroke-like episodes) [168] and infantile mitochondrial encephalopathy and complex I deficiency [169], respectively. However, in the case of the ND6 subunit, the transfer of mtDNA carrying a mutation in the gene encoding this subunit to the other nuclear background exhibited a positive effect even in the absence of ND6 protein synthesis: Complex I assembly and functioning recovered [170]. Such nuclear suppression of the mitochondrial defect was also found in the case of the ND5 subunit [170]. This suggests that cross-talk between nuclear and mitochondrial genomes plays an important role in the maintenance of cell functioning. Such bidirectional cross-talk might include nuclear-encoded microRNAs influencing the expression of mitochondrial genes [171] and small mitochondrial highly transcribed RNAs (smithRNAs) regulating the expression of nuclear genes [172] and other known mechanisms (e.g., [173]). However, the applicability of such scenarios for mitochondrial dysfunction in PD requires direct experimental validation.

The role and mechanisms of nuclear suppression of mitochondrial defects clearly need better understanding as it represents a promising area for therapeutic interventions. This will be particularly interesting in the context of PD therapy.

Author Contributions: Data analysis, O.B., V.F., A.K., and A.M.; writing-original draft preparation, O.B., V.F., and A.M.; writing-review and editing, O.B., A.K., and A.M.; supervision, A.M. All authors have read and agreed to the published version of the manuscript.

Funding: This work performed within the framework of the Program for Basic Research of State Academies of Sciences for 2013-2020 was partially supported by the Russian Foundation for Basic Research (project no.19-015-00073a).

Conflicts of Interest: The authors declare no conflict of interest.

\section{References}

1. Goetz, C.G. The history of Parkinson's disease: Early clinical descriptions and neurological therapies. Cold Spring Harb. Perspect. Med. 2011, 1, a008862. [CrossRef] [PubMed]

2. Obeso, J.A.; Stamelou, M.; Goetz, C.G.; Poewe, W.; Lang, A.E.; Weintraub, D.; Burn, D.; Halliday, G.M.; Bezard, E.; Przedborski, S.; et al. Past, present, and future of Parkinson's disease: A special essay on the 200th anniversary of the Shaking Palsy. Mov. Disord. 2017, 32, 1264-1310. [CrossRef] [PubMed] 
3. Klein, C.; Westenberger, A. Genetics of Parkinson's disease. Cold Spring Harb. Perspect. Med. 2012, 2, a008888. [CrossRef] [PubMed]

4. Langston, J.W.; Langston, E.B.; Irwin, I. MPTP-induced parkinsonism in human and non-human primates-clinical and experimental aspects. Acta Neurologica Scandinavica 1984, 100, 49-54. [PubMed]

5. Schapira, A.H.; Cooper, J.M.; Dexter, D.; Jenner, P.; Clark, J.B.; Marsden, C.D. Mitochondrial complex I deficiency in Parkinson's disease. Lancet 1989, 1, 1269. [CrossRef]

6. Schapira, A.H.; Mann, V.M.; Cooper, J.M.; Dexter, D.; Daniel, S.E.; Jenner, P.; Clark, J.B.; Marsden, C.D. Anatomic and disease specificity of NADH CoQ1 reductase (complex I) deficiency in Parkinson's disease. J. Neurochem. 1990, 55, 2142-2145. [CrossRef]

7. Blin, O.; Desnuelle, C.; Rascol, O.; Borg, M.; Peyro Saint Paul, H.; Azulay, J.P.; Billé, F.; Figarella, D.; Coulom, F.; Pellissier, J.F.; et al. Mitochondrial respiratory failure in skeletal muscle from patients with Parkinson's disease and multiple system atrophy. J. Neurol. Sci. 1994, 125, 95-101. [CrossRef]

8. Cardellach, F.; Marti, M.J.; Fernandez-Sola, J.; Marin, C.; Hoek, J.B.; Tolosa, E.; Urbano-Marquez, A. Mitochondrial respiratory chain activity in skeletal muscle from patients with Parkinson's disease. Neurology 1993, 43, 2258-2262. [CrossRef]

9. Haas, R.H.; Nasirian, F.; Nakano, K.; Ward, D.; Pay, M.; Hill, R.; Shults, C.W. Low platelet mitochondrial complex I and complex II/III activity in early untreated Parkinson's disease. Ann. Neurol. 1995, 37, 714-722. [CrossRef]

10. Yoshino, H.; Nakagawa-Hattori, Y.; Kondo, T.; Mizuno, Y. Mitochondrial complex I and II activities of lymphocytes and platelets in Parkinson's disease. J. Neural. Transm. Parkinson's Dis. Dement. Sect. 1992, 4, 27-34. [CrossRef]

11. Mytilineou, C.; Werner, P.; Molinari, S.; Di Rocco, A.; Cohen, G.; Yahr, M.D. Impaired oxidative decarboxylation of pyruvate in fibroblasts from patients with Parkinson's disease. J. Neural Transm. Park. Dis. Dement. Sect. 1994, 8, 223-228. [CrossRef] [PubMed]

12. Swerdlow, R.H. Does mitochondrial DNA play a role in Parkinson's disease? A review of cybrid and other supportive evidence. Antioxid. Redox Signal. 2012, 16, 950-964. [CrossRef] [PubMed]

13. Nass, M.M.K.; Nass, S. Intramitochondrial fibers with DNA characteristics: I. Fixation and electron staining reactions. J. Cell Biol. 1963, 9, 593-611. [CrossRef] [PubMed]

14. Nass, S.; Nass, M.M.K. Intramitochondrial fibers with DNA characteristics: II. Enzymatic and other hydrolytic treatments. J. Cell Biol. 1963, 9, 613-629. [CrossRef] [PubMed]

15. Watanabe, K. Unique features of animal mitochondrial translation systems-The non-universal genetic code, unusual features of the translational apparatus and their relevance to human mitochondrial diseases. Proc. Jpn. Acad. Ser. B Phys. Biol. Sci. 2010, 86, 11-39. [CrossRef]

16. Greber, B.; Ban, N. Structure and function of the mitochondrial ribosome. Ann. Rev. Biochem. 2016, 85, 103-132. [CrossRef]

17. Anderson, S.; Bankier, A.T.; Barrell, B.G.; de Bruijn, M.H.; Coulson, A.R.; Drouin, J.; Eperon, I.C.; Nierlich, D.P.; Roe, B.A.; Sanger, F.; et al. Sequence and organization of the human mitochondrial genome. Nature 1981, 290, 457-465. [CrossRef]

18. Gray, M.W.; Lang, B.F.; Cedergren, R.; Golding, G.B.; Lemieux, C.; Sankoff, D.; Turmel, M.; Brossard, N.; Delage, E.; Littlejohn, T.G.; et al. Genome structure and gene content in protist mitochondrial DNAs. Nucleic Acids Res. 1998, 26, 865-878. [CrossRef]

19. Kogelnik, A.M.; Lott, M.T.; Brown, M.D.; Navathe, S.B.; Wallace, D.C. MITOMAP: A human mitochondrial genome database. Nucleic Acids Res. 1996, 24, 177-179. [CrossRef]

20. Greaves, L.C.; Reeve, A.K.; Taylor, R.W.; Turnbull, D.M. Mitochondrial DNA and disease. J. Pathol. 2012, 226, 274-286. [CrossRef]

21. Vinothkumar, K.R.; Zhu, J.; Hirst, J. Architecture of mammalian respiratory complex I. Nature 2014, 515, 80-84. [CrossRef] [PubMed]

22. Xia, D.; Esser, L.; Tang, W.-K.; Zhou, F.; Zhou, Y.; Yu, L.; Yu, C.-A. Structural analysis of cytochrome bc1 complexes: Implications to the mechanism of function. Biochim. Biophys. Acta (BBA) Bioenergetics 2013, 1827, 1278-1294. [CrossRef] [PubMed]

23. Kadenbach, B.; Hüttemann, M. The subunit composition and function of mammalian cytochrome $c$ oxidase. Mitochondrion 2015, 24, 64-76. [CrossRef] [PubMed] 
24. Sousa, J.S.; D’Imprima, E.; Vonck, J. Mitochondrial respiratory chain complexes. Subcell. Biochem. 2018, 87, 167-227. [PubMed]

25. Jonckheere, A.I.; Smeitink, J.A.; Rodenburg, R.J. Mitochondrial ATP synthase: Architecture, function and pathology. J. Inherit. Metab. Dis. 2012, 35, 211-225. [CrossRef]

26. Marchington, D.R.; Scott Brown, M.S.G.; Lamb, V.K.; van Golde, R.J.T.; Kremer, J.A.M.; Tuerlings, J.H.A.M.; Mariman, E.C.M.; Balen, A.H.; Poulton, J. No evidence for paternal mtDNA transmission to offspring or extra-embryonic tissues after ICSI. Mol. Hum. Reprod. 2002, 8, 1046-1049. [CrossRef]

27. Danan, C.; Sternberg, D.; Van Steirteghem, A.; Cazeneuve, C.; Duquesnoy, P.; Besmond, C.; Goosens, M.; Lissens, W.; Amselem, S. Evaluation of parental mitochondrial inheritance in neonates born after intracytoplasmic sperm injection. Am. J. Hum. Genet. 1999, 65, 463-473. [CrossRef]

28. Houshmand, M.; Holme, E.; Hanson, C.; Wennerholm, U.B.; Hamberger, L. Is paternal mitochondrial DNA transferred to the offspring following intracytoplasmic sperm injection? J. Assist. Reprod. Genet. 1997, 14, 223-227. [CrossRef]

29. Sutovsky, P.; Moreno, R.D.; Ramalho-Santos, J.; Dominko, T.; Simerly, C.; Schatten, G. Ubiquitin tag for sperm mitochondria. Nature 1999, 402, 371-372. [CrossRef]

30. Song, W.-H.; Ballard, J.W.O.; Yi, Y.-J.; Sutovsky, P. Regulation of mitochondrial genome inheritance by autophagy and ubiquitin-proteasome system: Implications for health, fitness, and fertility. Biomed. Res. Int. 2014, 2014, 981867. [CrossRef]

31. Buneeva, O.A.; Medvedev, A.E. Mitochondrial dysfunction in Parkinson's disease. Biomed. Khim. 2011, 57, 246-281. [CrossRef]

32. Wallace, D.C.; Chalkia, D. Mitochondrial DNA genetics and the heteroplasmy conundrum in evolution and disease. Cold Spring Harb. Perspect. Biol. 2013, 5, a021220. [CrossRef] [PubMed]

33. Alexeyev, M. Mitochondrial DNA: The common confusions. Mitochondrial DNA Part A 2020, 31, 45-47. [CrossRef] [PubMed]

34. Falkenberg, M. Mitochondrial DNA replication in mammalian cells: Overview of the pathway. Essays Biochem. 2018, 62, 287-296. [PubMed]

35. Nicholls, T.J.; Minczuk, M. In D-loop: 40 years of mitochondrial 7S DNA. Exp. Gerontol. 2014, 56, $175-181$. [CrossRef]

36. Yasukawa, T.; Kang, D. An overview of mammalian mitochondrial DNA replication mechanisms. J. Biochem. 2018, 164, 183-193. [CrossRef]

37. King, M.P.; Attardi, G. Isolation of human cell lines lacking mitochondrial DNA. Methods Enzymol. 1996, 264, 304-313.

38. Gilkerson, R.; Bravo, L.; Garcia, I.; Gaytan, N.; Herrera, A.; Maldonado, A.; Quintanilla, B. The mitochondrial nucleoid: Integrating mitochondrial DNA into cellular homeostasis. Cold Spring Harb. Perspect. Biol. 2013, 5 , a011080. [CrossRef]

39. Farge, G.; Falkenberg, M. Organization of DNA in mammalian mitochondria. Int. J. Mol. Sci. 2019, $20,2770$. [CrossRef]

40. Kaufman, B.A.; Newman, S.M.; Hallberg, R.L.; Slaughter, C.A.; Perlman, P.S.; Butow, R.A. In organello formaldehyde crosslinking of proteins to mtDNA: Identification of bifunctional proteins. Proc. Natl. Acad. Sci. USA 2000, 97, 7772-7777. [CrossRef]

41. Wang, Y.; Bogenhagen, D.F. Human mitochondrial DNA nucleoids are linked to protein folding machinery and metabolic enzymes at the mitochondrial inner membrane. J. Biol. Chem. 2006, 281, 25791-25802. [CrossRef] [PubMed]

42. Bogenhagen, D.F.; Rousseau, D.; Burke, S. The layered structure of human mitochondrial DNA nucleoids. J. Biol. Chem. 2008, 283, 3665-3675. [CrossRef] [PubMed]

43. Choi, Y.-S.; Jeong, J.H.; Min, H.-K.; Jung, H.-J.; Hwang, D.; Lee, S.-W.; Pak, Y.K. Shot-gun proteomic analysis of mitochondrial D-loop DNA binding proteins: Identification of mitochondrial histones. Mol. Biosyst. 2011, 7, 1523-1536. [CrossRef] [PubMed]

44. He, J.; Cooper, H.M.; Reyes, A.; Di Re, M.; Sembongi, H.; Litwin, T.R.; Gao, J.; Neuman, K.C.; Fearnley, I.M.; Spinazzola, A.; et al. Mitochondrial nucleoid interacting proteins support mitochondrial protein synthesis. Nucleic Acids Res. 2012, 40, 6109-6121. [CrossRef] [PubMed] 
45. Hensen, F.; Cansiz, S.; Gerhold, J.M.; Spelbrink, J.N. To be or not to be a nucleoid protein: A comparison of mass-spectrometry based approaches in the identification of potential mtDNA-nucleoid associated proteins. Biochimie 2014, 100, 219-226. [CrossRef] [PubMed]

46. Han, S.; Udeshi, N.D.; Deerinck, T.J.; Svinkina, T.; Ellisman, M.H.; Carr, S.A.; Ting, A.Y. Proximity Biotinylation as a method for mapping proteins associated with mtDNA in living cells. Cell Chem. Biol. 2017, 24, 404-414. [CrossRef] [PubMed]

47. Trinkle-Mulcahy, L. Recent advances in proximity-based labeling methods for interactome mapping. Version 1. F1000Ressearch 2019, 8. [CrossRef]

48. Kopek, B.G.; Shtengel, G.; Xu, C.S.; Clayton, D.A.; Hess, H.F. Correlative 3D superresolution fluorescence and electron microscopy reveal the relationship of mitochondrial nucleoids to membranes. Proc. Natl. Acad. Sci. USA 2012, 109, 6136-6141. [CrossRef]

49. Qin, J.; Guo, Y.; Xue, B.; Shi, P.; Chen, Y.; Su, Q.P.; Hao, H.; Zhao, S.; Wu, C.; Yu, L.; et al. ER-mitochondria contacts promote mtDNA nucleoids active transportation via mitochondrial dynamic tubulation. Nat. Commun. 2020, 11, 4471. [CrossRef]

50. Robberson, D.L.; Kasamatsu, H.; Vinograd, J. Replication of mitochondrial DNA. Circular replicative intermediates in mouse L cells. Proc. Natl. Acad. Sci. USA 1972, 69, 737-741. [CrossRef]

51. Miralles Fusté, J.M.; Wanrooij, S.; Jemt, E.; Granycome, C.E.; Cluett, T.J.; Shi, Y.; Atanassova, N.; Holt, I.J.; Gustafsson, C.M.; Falkenberg, M. Mitochondrial RNA polymerase is needed for activation of the origin of light-strand DNA replication. Mol. Cell 2010, 37, 67-78. [CrossRef] [PubMed]

52. Miralles Fusté, J.; Shi, Y.; Wanrooij, S.; Zhu, X.; Jemt, E.; Persson, Ö.; Sabouri, N.; Gustafsson, C.M.; Falkenberg, M. In vivo occupancy of mitochondrial single-stranded DNA binding protein supports the strand displacement mode of DNA replication. PLoS Genet. 2014, 10, e1004832. [CrossRef] [PubMed]

53. Hsieh, C.-L. Novel lines of evidence for the asymmetric strand displacement model of mitochondrial DNA replication. Mol. Cell. Biol. 2019, 39, e00406-18. [CrossRef] [PubMed]

54. Agaronyan, K.; Morozov, Y.I.; Anikin, M.; Temiakov, D. Mitochondrial biology. Replication-transcription switch in human mitochondria. Science 2015, 347, 548-551. [CrossRef]

55. D'Souza, A.R.; Minczuk, M. Mitochondrial transcription and translation: Overview. Essays Biochem. 2018, 62, 309-320. [PubMed]

56. Posse, V.; Gustafsson, C.M. Human mitochondrial transcription factor B2 is required for promoter melting during initiation of transcription. J. Biol. Chem. 2017, 292, 2637-2645. [CrossRef]

57. Litonin, D.; Sologub, M.; Shi, Y.; Savkina, M.; Anikin, M.; Falkenberg, M.; Gustafsson, C.M.; Temiakov, D. Human mitochondrial transcription revisited: Only TFAM and TFB2M are required for transcription of the mitochondrial genes in vitro. J. Biol. Chem. 2010, 285, 18129-18133. [CrossRef]

58. Jiang, S.; Koolmeister, C.; Misic, J.; Siira, S.; Kühl, I.; Silva Ramos, E.; Miranda, M.; Jiang, M.; Posse, V.; Lytovchenko, O.; et al. TEFM regulates both transcription elongation and RNA processing in mitochondria. EMBO Rep. 2019, 20, e48101. [CrossRef]

59. Tomecki, R.; Dmochowska, A.; Gewartowski, K.; Dziembowski, A.; Stepien, P.P. Identification of a novel human nuclear-encoded mitochondrial poly(A) polymerase. Nucleic Acids Res. 2004, 32, 6001-6014. [CrossRef]

60. Nagaike, T.; Suzuki, T.; Katoh, T.; Ueda, T. Human mitochondrial mRNAs are stabilized with polyadenylation regulated by mitochondria-specific poly(A) polymerase and polynucleotide phosphorylase. J. Biol. Chem. 2005, 280, 19721-19727. [CrossRef]

61. Lapkouski, M.; Hällberg, B.M. Structure of mitochondrial poly(A) RNA polymerase reveals the structural basis for dimerization, ATP selectivity and the SPAX4 disease phenotype. Nucleic Acids Res. 2015, 43, 9065-9075. [CrossRef] [PubMed]

62. Ruzzenente, B.; Metodiev, M.D.; Wredenberg, A.; Bratic, A.; Park, C.B.; Cámara, Y.; Milenkovic, D.; Zickermann, V.; Wibom, R.; Hultenby, K.; et al. LRPPRC is necessary for polyadenylation and coordination of translation of mitochondrial mRNAs. EMBO J. 2012, 31, 443-456. [CrossRef] [PubMed]

63. Cui, J.; Wang, L.; Ren, X.; Zhang, Y.; Zhang, H. LRPPRC: A multifunctional protein involved in energy metabolism and human disease. Front. Physiol. 2019, 10, 595. [CrossRef] [PubMed]

64. Linnane, A.W.; Marzuki, S.; Ozawa, T.; Tanaka, M. Mitochondrial DNA mutations as an important contributor to ageing and degenerative diseases. Lancet 1989, 1, 642-645. [CrossRef] 
65. Kruman, I.I.; Wersto, R.P.; Cardozo-Pelaez, F.; Smilenov, L.; Chan, S.L.; Chrest, F.J.; Emokpae, R., Jr.; Gorospe, M.; Mattson, M.P. Cell cycle activation linked to neuronal cell death initiated by DNA damage. Neuron 2004, 41, 549-561. [CrossRef]

66. Nakabeppu, Y.; Tsuchimoto, D.; Yamaguchi, H.; Sakumi, K. Oxidative damage in nucleic acids and Parkinson's disease. J. Neurosci. Res. 2007, 85, 919-934. [CrossRef]

67. Santos, R.X.; Correia, S.C.; Zhu, X.; Smith, M.A.; Moreira, P.I.; Castellani, R.J.; Nunomura, A.; Perry, G. Mitochondrial DNA oxidative damage and repair in aging and Alzheimer's disease. Antioxid. Redox Signal. 2013, 18, 2444-2457. [CrossRef]

68. Yakes, F.M.; Van Houten, B. Mitochondrial DNA damage is more extensive and persists longer than nuclear DNA damage in human cells following oxidative stress. Proc. Natl. Acad. Sci. USA 1997, 94, 514-519. [CrossRef]

69. Horowitz, M.P.; Greenamyre, J.T. Mitochondrial iron metabolism and its role in neurodegeneration. J. Alzheimers Dis. 2010, 20 (Suppl. 2), S551-S568. [CrossRef]

70. Sies, H. Strategies of antioxidant defense. Eur. J. Biochem. 1993, 215, 213-219. [CrossRef]

71. Cooke, M.S.; Evans, M.D.; Dizdaroglu, M.; Lunec, J. Oxidative DNA damage: Mechanisms, mutation, and disease. FASEB J. 2003, 17, 1195-1214. [CrossRef] [PubMed]

72. Yoshimura, D.; Sakumi, K.; Ohno, M.; Sakai, Y.; Furuichi, M.; Iwai, S.; Nakabeppu, Y. An oxidized purine nucleoside triphosphatase, MTH1, suppresses cell death caused by oxidative stress. J. Biol. Chem. 2003, 278, 37965-37973. [CrossRef] [PubMed]

73. Krokan, H.E.; Bjørås, M. Base excision repair. Cold Spring Harb. Perspect. Biol. 2013, 5, a012583. [CrossRef] [PubMed]

74. Nishioka, K.; Ohtsubo, T.; Oda, H.; Fujiwara, T.; Kang, D.; Sugimachi, K.; Nakabeppu, Y. Expression and differential intracellular localization of two major forms of human 8-oxoguanine DNA glycosylase encoded by alternatively spliced OGG1 mRNAs. Mol. Biol Cell. 1999, 10, 1637-1652. [CrossRef]

75. De Souza-Pinto, N.C.; Eide, L.; Hogue, B.A.; Thybo, T.; Stevnsner, T.; Seeberg, E.; Klungland, A.; Bohr, V.A. Repair of 8-oxodeoxyguanosine lesions in mitochondrial dna depends on the oxoguanine dna glycosylase (OGG1) gene and 8-oxoguanine accumulates in the mitochondrial dna of OGG1-defective mice. Cancer Res. 2001, 61, 5378-5381.

76. Yamaguchi, H.; Kajitani, K.; Dan, Y.; Furuichi, M.; Ohno, M.; Sakumi, K.; Kang, D.; Nakabeppu, Y. MTH1, an oxidized purine nucleoside triphosphatase, protects the dopamine neurons from oxidative damage in nucleic acids caused by 1-methyl-4-phenyl-1,2,3,6- tetrahydropyridine. Cell Death Differ. 2006, 13, 551-563. [CrossRef]

77. Lauritzen, K.H.; Dalhus, B.; Storm, J.F.; Bjørås, M.; Klungland, A. Modeling the impact of mitochondrial DNA damage in forebrain neurons and beyond. Mech. Ageing Dev. 2011, 132, 424-428. [CrossRef]

78. Lauritzen, K.H.; Moldestad, O.; Eide, L.; Carlsen, H.; Nesse, G.; Storm, J.F.; Mansuy, I.M.; Bergersen, L.H.; Klungland, A. Mitochondrial DNA toxicity in forebrain neurons causes apoptosis, neurodegeneration, and impaired behavior. Mol. Cell Biol. 2010, 30, 1357-1367. [CrossRef]

79. Rothfuss, O.; Gasser, T.; Patenge, N. Analysis of differential DNA damage in the mitochondrial genome employing a semi-long run real-time PCR approach. Nucl. Acids Res. 2010, 38, e24. [CrossRef]

80. Collins, A. Comparison of different methods of measuring 8- oxoguanine as a marker of oxidative DNA damage. Free Radic. Res. 2000, 32, 333-341. [CrossRef]

81. Pilger, A.; Rüdiger, H.W. 8-Hydroxy-2'-deoxyguanosine as a marker of oxidative DNA damage related to occupational and environmental exposures. Int. Arch. Occup. Environ. Health 2006, 80, 1-15. [CrossRef] [PubMed]

82. Mecocci, P.; Beal, M.F.; Cecchetti, R.; Polidori, M.C.; Cherubini, A.; Chionne, F.; Avellini, L.; Romano, G.; Senin, U. Mitochondrial membrane fluidity and oxidative damage to mitochondrial DNA in aged and AD human brain. Mol. Chem. Neuropathol. 1997, 31, 53-64. [CrossRef] [PubMed]

83. Barja, G.; Herrero, I. Oxidative damage to mitochondrial DNA is inversely related to maximum life span in the heart and brain of mammals. FASEB J. 2000, 14, 312-318. [CrossRef] [PubMed]

84. Chen, D.; Cao, G.; Hastings, T.; Feng, Y.; Pei, W.; O’Horo, C.; Chen, J. Age-dependent decline of DNA repair activity for oxidative lesions in rat brain mitochondria. J. Neurochem. 2002, 81, 1273-1284. [CrossRef] 
85. Imam, S.Z.; Karahalil, B.; Hogue, B.A.; Souza-Pinto, N.C.; Bohr, V.A. Mitochondrial and nuclear DNA-repair capacity of various brain regions in mouse is altered in an age-dependent manner. Neurobiol. Aging. 2006, 27, 1129-1136. [CrossRef]

86. Gredilla, R.; Garm, C.; Holm, R.; Bohr, V.A.; Stevnsner, T. Differential age-related changes in mitochondrial DNA repair activities in mouse brain regions. Neurobiol. Aging 2010, 31, 993-1002. [CrossRef]

87. Fukae, J.; Takanashi, M.; Kubo, S.-I.; Nishioka, K.-I.; Nakabeppu, Y.; Mori, H.; Mizuno, Y.; Hattori, N. Expression of 8-oxoguanine DNA glycosylase (OGG1) in Parkinson's disease and related neurodegenerative disorders. Acta Neurophathol. 2005, 109, 256-262. [CrossRef]

88. Sondheimer, N.; Glatz, C.E.; Tirone, J.E.; Deardorff, M.A.; Krieger, A.M.; Hakonarson, H. Neutral mitochondrial heteroplasmy and the influence of aging. Hum. Mol. Genet. 2011, 20, 1653-1659. [CrossRef]

89. Bender, A.; Krishnan, K.J.; Morris, C.M.; Taylor, G.A.; Reeve, A.K.; Perry, R.H.; Jaros, E.; Hersheson, J.S.; Betts, J.; Klopstock, T.; et al. High levels of mitochondrial DNA deletions in substantia nigra neurons in aging and Parkinson disease. Nat. Genet. 2006, 38, 515-517. [CrossRef]

90. Kraytsberg, Y.; Kudryavtseva, E.; McKee, A.C.; Geula, C.; Kowall, N.W.; Khrapko, K. Mitochondrial DNA deletions are abundant and cause functional impairment in aged human substantia nigra neurons. Nat. Genet. 2006, 38, 518-520. [CrossRef]

91. Dölle, C.; Flønes, I.; Nido, G.S.; Miletic, H.; Osuagwu, N.; Kristoffersen, S.; Lilleng, P.K.; Larsen, J.P.; Tysnes, O.B.; Haugarvoll, K.; et al. Defective mitochondrial DNA homeostasis in the substantia nigra in Parkinson disease. Nat. Commun. 2016, 7, 13548. [CrossRef] [PubMed]

92. Hebert, S.L.; Lanza, I.R.; Nair, K.S. Mitochondrial DNA alterations and reduced mitochondrial function in aging. Mech. Ageing Dev. 2010, 131, 451-462. [CrossRef] [PubMed]

93. Vives-Bauza, C.; Andreu, A.L.; Manfredi, G.; Beal, M.F.; Janetzky, B.; Gruenewald, T.H.; Lin, M.T. Sequence analysis of the entire mitochondrial genome in Parkinson's disease. Biochem. Biophys. Res. Commun. 2002, 290, 1593-1601. [CrossRef] [PubMed]

94. Gu, G.; Reyes, P.E.; Golden, G.T.; Woltjer, R.L.; Hulette, C.; Montine, T.J.; Zhang, J. Mitochondrial DNA deletions/rearrangements in parkinson disease and related neurodegenerative disorders. J. Neuropathol. Exp. Neurol. 2002, 61, 634-639. [CrossRef]

95. Mayr-Wohlfart, U.; Rödel, G.; Henneberg, A. Mitochondrial tRNA(Gln) and tRNA(Thr) gene variants in Parkinson's disease. Eur. J. Med. Res. 1997, 2, 111-113.

96. Brown, M.D.; Shoffner, J.M.; Kim, Y.L.; Jun, A.S.; Graham, B.H.; Cabell, M.F.; Gurley, D.S.; Wallace, D.C. Mitochondrial DNA sequence analysis of four Alzheimer's and Parkinson's disease patients. Am. J. Med. Genet. 1996, 61, 283-289. [CrossRef]

97. Egensperger, R.; Kösel, S.; Schnopp, N.M.; Mehraein, P.; Graeber, M.B. Association of the mitochondrial tRNA(A4336G) mutation with Alzheimer's and Parkinson's diseases. Neuropathol. Appl. Neurobiol. 1997, 23, 315-321. [CrossRef]

98. Richter, G.; Sonnenschein, A.; Grünewald, T.; Reichmann, H.; Janetzky, B. Novel mitochondrial DNA mutations in Parkinson's disease. J. Neural Transm. 2002, 109, 721-729. [CrossRef]

99. Huerta, C.; Castro, M.G.; Coto, E.; Blázquez, M.; Ribacoba, R.; Guisasola, L.M.; Salvador, C.; Martínez, C.; Lahoz, C.H.; Alvarez, V. Mitochondrial DNA polymorphisms and risk of Parkinson's disease in Spanish population. J. Neurol. Sci. 2005, 236, 49-54. [CrossRef]

100. García-Lozano, J.R.; Mir, P.; Alberca, R.; Aguilera, I.; Gil Néciga, E.; Fernández-López, O.; Cayuela, A.; Núñez-Roldan, A. Mitochondrial DNA A4336G mutation in Alzheimer's and Parkinson's diseases. Eur. Neurol. 2002, 48, 34-36. [CrossRef]

101. Cavelier, L.; Erikson, I.; Tammi, M.; Jalonen, P.; Lindholm, E.; Jazin, E.; Smith, P.; Luthman, H.; Gyllensten, U. MtDNA mutations in maternally inherited diabetes: Presence of the 3397 ND1 mutation previously associated with Alzheimer's and Parkinson's disease. Hereditas 2001, 135, 65-70. [CrossRef] [PubMed]

102. Horvath, R.; Kley, R.A.; Lochmu“ller, H.; Vorgerd, M. Parkinson syndrome, neuropathy, and myopathy caused by the mutation A8344G (MERRF) in tRNALys. Neurology 2007, 68, 56-58. [CrossRef] [PubMed]

103. Shoffner, J.M.; Brown, M.D.; Torroni, A.; Lott, M.T.; Cabell, M.F.; Mirra, S.S.; Beal, M.F.; Yang, C.C.; Gearing, M.; Salvo, R.; et al. Mitochondrial DNA variants observed in Alzheimer disease and Parkinson disease patients. Genomics 1993, 17, 171-184. [CrossRef] [PubMed] 
104. Thyagarajan, D.; Bressman, S.; Bruno, C.; Przedborski, S.; Shanske, S.; Lynch, T.; Fahn, S.; DiMauro, S. A novel mitochondrial 12SrRNA point mutation in parkinsonism, deafness, and neuropathy. Ann. Neurol. 2000, 48, 730-736. [CrossRef]

105. Hudson, G.; Nalls, M.; Evans, J.R.; Breen, D.P.; Winder-Rhodes, S.; Morrison, K.E.; Morris, H.R.; Williams-Gray, C.H.; Barker, R.A.; Singleton, A.B.; et al. Two-stage association study and meta-analysis of mitochondrial DNA variants in Parkinson disease. Neurology 2013, 80, 2042-2048. [CrossRef] [PubMed]

106. Ross, O.A.; McCormack, R.; Maxwell, L.D.; Duguid, R.A.; Quinn, D.J.; Barnett, Y.A.; Rea, I.M.; El-Agnaf, O.M.; Gibson, J.M.; Wallace, A.; et al. mt4216C variant in linkage with the mtDNA TJ cluster may confer a susceptibility to mitochondrial dysfunction resulting in an increased risk of Parkinson's disease in the Irish. Exp. Gerontol. 2003, 38, 397-405. [CrossRef]

107. Janetzky, B.; Schmid, C.; Bischof, F.; Frölich, L.; Gsell, W.; Kalaria, R.N.; Riederer, P.; Reichmann, H. Investigations on the point mutation at position 5460 of the mtDNA in different neurodegenerative and neuromuscular diseases. Eur. Neurol. 1996, 36, 149-153. [CrossRef] [PubMed]

108. Lin, F.H.; Lin, R.; Wisniewski, H.M.; Hwang, Y.W.; Grundke Iqbal, I.; Healy Louie, G.; Iqbal, K. Detection of point mutations in codon 331 of mitochondrial NADH dehydrogenase subunit 2 in Alzheimer's brains. Biochem. Biophys. Res. Commun. 1992, 182, 238-246. [CrossRef]

109. Zhang, J.; Montine, T.J.; Smith, M.A.; Siedlak, S.L.; Gu, G.; Robertson, D.; Perry, G. The mitochondrial common deletion in Parkinson's disease and related movement disorders. Parkinsonism Relat. Disord. 2002, 8, 165-170. [CrossRef]

110. Wei, Y.H. Mitochondrial DNA alterations as ageing-associated molecular events. Mutat. Res. 1992, 275, 145-155. [CrossRef]

111. Smigrodzki, R.; Parks, J.; Parker, W.D. High frequency of mitochondrial complex I mutations in Parkinson's disease and aging. Neurobiol. Aging 2004, 25, 1273-1281. [CrossRef] [PubMed]

112. Taravari, A.; Panov, S.; Petrov, I.; Petrova, V.; Medziti, F.; Haliti, G. Delta deletion 4977 in mitochondrial DNA in patients with idiopathic Parkinson's disease. Bratisl. Lek. Listy. 2014, 115, 7-13. [CrossRef] [PubMed]

113. Gusdon, A.M.; Fang, F.; Chen, J.; Mathews, C.E.; Li, W.; Chu, C.T.; Ding, J.Q.; Chen, S.D. Association of the mt-ND2 5178A/C polymorphism with Parkinson's disease. Neurosci. Lett. 2015, 587, 98-101. [CrossRef] [PubMed]

114. Vives-Bauza, C.; Gonzalo, R.; Manfredi, G.; Garcia-Arumi, E.; Andreu, A.L. Enhanced ROS production and antioxidant defenses in cybrids harbouring mutations in mtDNA. Neurosci. Lett. 2006, 391, 136-141. [CrossRef]

115. Bruno, C.; Martinuzzi, A.; Tang, Y.; Andreu, A.L.; Pallotti, F.; Bonilla, E.; Shanske, S.; Fu, J.; Angelini, C.; DiMauro, S.; et al. A stop-codon mutation in the human mtDNA cytochrome $c$ oxidase I gene disrupts the functional structure of complex IV. Am. J. Hum. Genet. 1999, 65, 611-620. [CrossRef]

116. D'Aurelio, M.; Palloti, F.; Barrientos, A.; Gajewski, C.D.; Kwong, J.Q.; Bruno, C.; Beal, M.F.; Manfredi, G. In vivo regulation of oxidative phosphorylation in cells harboring a stop-codon mutation in mitochondrial DNA-encoded cytochrome c oxidase subunit I. J. Biol. Chem. 2001, 276, 46925-46932. [CrossRef]

117. Van der Walt, J.M.; Nicodemus, K.K.; Martin, E.R.; Scott, W.K.; Nance, M.A.; Watts, R.L.; Hubble, J.P.; Haines, J.L.; Koller, W.C.; Lyons, K.; et al. Mitochondrial polymorphisms significantly reduce the risk of Parkinson disease. Am. J. Hum. Genet. 2003, 72, 804-811. [CrossRef]

118. Autere, J.; Moilanen, J.S.; Finnilä, S.; Soininen, H.; Mannermaa, A.; Hartikainen, P.; Hallikainen, M.; Majamaa, K. Mitochondrial DNA polymorphisms as risk factors for Parkinson's disease and Parkinson's disease dementia. Hum. Genet. 2004, 115, 29-35.

119. Parker, W.D.; Parks, J.K. Mitochondrial ND5 mutations in idiopathic Parkinson's disease. Biochem. Biophys. Res. Commun. 2005, 326, 667-669. [CrossRef]

120. Gonzalo, R.; Garcia-Arumi, E.; Llige, D.; Martia, R.; Solano, A.; Montoya, J.; Arenasd, J.; Andreua, A.L. Free radicals-mediated damage in transmitochondrial cells harboring the T14487C mutation in the ND6 gene of mtDNA. FEBS Lett. 2005, 579, 6909-6913. [CrossRef]

121. Solano, A.; Roig, M.; Vives-Bauza, C.; Hernandez-Pena, J.; Garcia-Arumi, E.; Playan, A.; Lopez-Perez, M.J.; Andreu, A.L.; Montoya, J. Bilateral Striatal Necrosis Associated with a Novel Mutation in the Mitochondrial ND6 Gene. Ann. Neurol. 2003, 54, 527-530. [CrossRef] [PubMed] 
122. Wei, W.; Keogh, M.J.; Wilson, I.; Coxhead, J.; Ryan, S.; Rollinson, S.; Griffin, H.; Kurzawa-Akanbi, M.; Santibanez-Koref, M.; Talbot, K.; et al. Mitochondrial DNA point mutations and relative copy number in 1363 disease and control human brains. Acta Neuropathol. Commun. 2017, 5, 13. [CrossRef] [PubMed]

123. Simon, D.K.; Lin, M.T.; Zheng, L.; Liu, G.J.; Ahn, C.H.; Kim, L.M.; Mauck, W.M.; Twu, F.; Beal, M.F.; Johns, D.R. Somatic mitochondrial DNA mutations in cortex and substantia nigra in aging and Parkinson's disease. Neurobiol. Aging. 2004, 25, 71-81. [CrossRef]

124. Alam, Z.I.; Jenner, A.; Daniel, S.E.; Lees, A.J.; Cairns, N.; Marsden, D.; Jenner, P.; Halliwell, B.J. Oxidative DNA damage in the parkinsonian brain: An apparent selective increase in 8-hydroxyguanine levels in substantia nigra. J. Neurochem. 1997, 69, 1196-1203. [CrossRef] [PubMed]

125. Nido, G.S.; Dölle, C.; Flønes, I.; Tuppen, H.A.; Alves, G.; Tysnes, O.B.; Haugarvoll, K.; Tzoulis, C. Ultradeep mapping of neuronal mitochondrial deletions in Parkinson's disease. Neurobiol. Aging 2018, 63, 120-127. [CrossRef]

126. Podlesniy, P.; Puigròs, M.; Serra, N.; Fernández-Santiago, R.; Ezquerra, M.; Tolosa, E.; Trullas, R. Accumulation of mitochondrial 7S DNA in idiopathic and LRRK2 associated Parkinson's disease. EBioMedicine 2019, 48, 554-567. [CrossRef]

127. Swerdlow, R.H. Mitochondria in cybrids containing mtDNA from persons with mitochondriopathies. J. Neurosci. Res. 2007, 85, 3416-3428. [CrossRef]

128. Wilkins, H.M.; Carl, S.M.; Swerdlow, R.H. Cytoplasmic hybrid (cybrid) cell lines as a practical model for mitochondriopathies. Redox Biol. 2014, 2, 619-631. [CrossRef]

129. Arduíno, D.M.; Esteves, A.R.; Swerdlow, R.H.; Cardoso, S.M. A cybrid cell model for the assessment of the link between mitochondrial deficits and sporadic Parkinson's disease. Methods Mol. Biol. 2015, 1265, 415-424.

130. Swerdlow, R.H.; Parks, J.K.; Miller, S.W.; Tuttle, J.B.; Trimmer, P.A.; Sheehan, J.P.; Bennett, J.P., Jr.; Davis, R.E.; Parker, W.D., Jr. Origin and functional consequences of the complex I defect in Parkinson's disease. Ann. Neurol. 1996, 40, 663-671. [CrossRef]

131. Gu, M.; Cooper, J.M.; Taanman, J.W.; Schapira, A.H. Mitochondrial DNA transmission of the mitochondrial defect in Parkinson's disease. Ann. Neurol. 1998, 44, 177-186. [CrossRef] [PubMed]

132. Esteves, A.R.; Domingues, A.F.; Ferreira, I.L.; Januario, C.; Swerdlow, R.H.; Oliveira, C.R.; Cardoso, S.M. Mitochondrial function in Parkinson's disease cybrids containing an nt2 neuron-like nuclear background. Mitochondrion 2008, 8, 219-228. [CrossRef] [PubMed]

133. Esteves, A.R.; Arduino, D.M.; Swerdlow, R.H.; Oliveira, C.R.; Cardoso, S.M. Oxidative stress involvement in alpha-synuclein oligomerization in Parkinsons disease cybrids. Antioxid. Redox Signal. 2009, 11, 439-448. [CrossRef] [PubMed]

134. Esteves, A.R.; Arduíno, D.M.; Swerdlow, R.H.; Oliveira, C.R.; Cardoso, S.M. Microtubule depolymerization potentiates alpha-synuclein oligomerization. Front. Aging Neurosci. 2010, 1, 5. [CrossRef] [PubMed]

135. Esteves, A.R.; Arduino, D.M.; Swerdlow, R.H.; Oliveira, C.R.; Cardoso, S.M. Dysfunctional mitochondria uphold calpain activation: Contribution to Parkinson's disease pathology. Neurobiol. Dis. 2010, 37, 723-730. [CrossRef] [PubMed]

136. Esteves, A.R.; Lu, J.; Rodova, M.; Onyango, I.; Lezi, E.; Dubinsky, R.; Lyons, K.E.; Pahwa, R.; Burns, J.M.; Cardoso, S.M.; et al. Mitochondrial respiration and respiration-associated proteins in cell lines created through Parkinson's subject mitochondrial transfer. J. Neurochem. 2010, 113, 674-682. [CrossRef]

137. Keeney, P.M.; Dunham, L.D.; Quigley, C.K.; Morton, S.L.; Bergquist, K.; Bennett, J.P., Jr. Cybrid models of Parkinson's disease show variable mitochondrial biogenesis and genotype respiration relationships. Exp. Neurol. 2009, 220, 374-382. [CrossRef]

138. Swerdlow, R.H.; Parks, J.K.; Cassarino, D.S.; Binder, D.R.; Bennett, J.P., Jr.; Di Iorio, G.; Golbe, L.I.; Parker, W.D., Jr. Biochemical analysis of cybrids expressing mitochondrial DNA from Contursi kindred Parkinson's subjects. Exp. Neurol. 2001, 169, 479-485. [CrossRef]

139. Aomi, Y.; Chen, C.S.; Nakada, K.; Ito, S.; Isobe, K.; Murakami, H.; Kuno, S.Y.; Tawata, M.; Matsuoka, R.; Mizusawa, H.; et al. Cytoplasmic transfer of platelet mtDNA from elderly patients with Parkinson's disease to mtDNA-less HeLa cells restores complete mitochondrial respiratory function. Biochem. Biophys. Res. Commun. 2001, 280, 265-273. [CrossRef]

140. Spinazzola, A.; Zeviani, M. Mitochondrial diseases: A cross-talk between mitochondrial and nuclear genomes. Adv. Exp. Med. Biol. 2009, 652, 69-84. 
141. Maret, G.; Testa, B.; Jenner, P.; el Tayar, N.; Carrupt, P.A. The MPTP story: MAO activates tetrahydropyridine derivatives to toxins causing parkinsonism. Drug Metab. Rev. 1990, 22, 291-332. [CrossRef] [PubMed]

142. Cookson, M.R. The biochemistry of Parkinson's disease. Annu. Rev. Biochem. 2005, 74, 9-52. [CrossRef] [PubMed]

143. Medvedev, A.E.; Buneeva, O.A.; Kopylov, A.T.; Tikhonova, O.V.; Medvedeva, M.V.; Nerobkova, L.N.; Kapitsa, I.G.; Zgoda, V.G. The brain mitochondrial subproteome of Rpn10-binding proteins and its changes induced by the neurotoxin MPTP and the neuroprotector isatin. Biochemistry (Moscow) 2017, 82, 330-333. [CrossRef] [PubMed]

144. Buneeva, O.; Kopylov, A.; Kapitsa, I.; Ivanova, E.; Zgoda, V.; Medvedev, A. The Effect of Neurotoxin MPTP and Neuroprotector Isatin on the Profile of Ubiquitinated Brain Mitochondrial Proteins. Cells 2018, 7, 91. [CrossRef]

145. Mandavilli, B.S.; Ali, S.F.; Van Houten, B. DNA damage in brain mitochondria caused by aging and MPTP treatment. Brain Res. 2000, 885, 45-52. [CrossRef]

146. Chen, L.J.; Gao, Y.Q.; Li, X.J.; Shen, D.H.; Sun, F.Y. Melatonin protects against MPTP/MPP+ -induced mitochondrial DNA oxidative damage in vivo and in vitro. J. Pineal. Res. 2005, 39, 34-42. [CrossRef]

147. Chin, M.H.; Qian, W.J.; Wang, H.; Petyuk, V.A.; Bloom, J.S.; Sforza, D.M.; Laćan, G.; Liu, D.; Khan, A.H.; Cantor, R.M.; et al. Mitochondrial dysfunction, oxidative stress, and apoptosis revealed by proteomic and transcriptomic analyses of the striata in two mouse models of Parkinson's disease. J. Proteome Res. 2008, 7, 666-677. [CrossRef]

148. Zhang, X.; Zhou, J.Y.; Chin, M.H.; Schepmoes, A.A.; Petyuk, V.A.; Weitz, K.K.; Petritis, B.O.; Monroe, M.E.; Camp, D.G.; Wood, S.A.; et al. Region-specific protein abundance changes in the brain of MPTP-induced Parkinson's disease mouse model. J. Proteome Res. 2010, 9, 1496-1509. [CrossRef]

149. Cannon, J.R.; Tapias, V.; Na, H.M.; Honick, A.S.; Drolet, R.E.; Greenamyre, J.T. A highly reproducible rotenone model of Parkinson's disease. Neurobiol. Dis. 2009, 34, 279-290. [CrossRef]

150. Sanders, L.H.; McCoy, J.; Hu, X.; Mastroberardino, P.G.; Dickinson, B.C.; Chang, C.J.; Chu, C.T.; Van Houten, B.; Greenamyre, J.T. Mitochondrial DNA damage: Molecular marker of vulnerable nigral neurons in Parkinson's disease. Neurobiol. Dis. 2014, 70, 214-223. [CrossRef]

151. Heinz, S.; Freyberger, A.; Lawrenz, B.; Schladt, L.; Schmuck, G.; Ellinger-Ziegelbauer, H. Mechanistic Investigations of the Mitochondrial Complex I Inhibitor Rotenone in the Context of Pharmacological and Safety Evaluation. Sci. Rep. 2017, 7, 45465. [CrossRef] [PubMed]

152. Karthikkeyan, G.; Najar, M.A.; Pervaje, R.; Pervaje, S.K.; Modi, P.K.; Prasad, T.S.K. Identification of Molecular Network Associated with Neuroprotective Effects of Yashtimadhu (Glycyrrhiza glabra L.) by Quantitative Proteomics of Rotenone-Induced Parkinson's Disease Model. ACS Omega 2020, 5, 26611-26625. [CrossRef] [PubMed]

153. Hance, N.; Ekstrand, M.I.; Trifunovic, A. Mitochondrial DNA polymerase gamma is essential for mammalian embryogenesis. Hum. Mol. Genet. 2005, 14, 1775-1783. [CrossRef] [PubMed]

154. Trifunovic, A.; Wredenberg, A.; Falkenberg, M.; Spelbrink, J.N.; Rovio, A.T.; Bruder, C.E.; Bohlooly-Y, M.; Gidlöf, S.; Oldfors, A.; Wibom, R.; et al. Premature ageing in mice expressing defective mitochondrial DNA polymerase. Nature 2004, 429, 417-423. [CrossRef] [PubMed]

155. Kujoth, G.C.; Hiona, A.; Pugh, T.D.; Someya, S.; Panzer, K.; Wohlgemuth, S.E.; Hofer, T.; Seo, A.Y.; Sullivan, R.; Jobling, W.A.; et al. Mitochondrial DNA mutations, oxidative stress, and apoptosis in mammalian aging. Science 2005, 309, 481-484. [CrossRef] [PubMed]

156. Vermulst, M.; Wanagat, J.; Kujoth, G.C.; Bielas, J.H.; Rabinovitch, P.S.; Prolla, T.A.; Loeb, L.A. DNA deletions and clonal mutations drive premature aging in mitochondrial mutator mice. Nat. Genet. 2008, 40, 392-394. [CrossRef] [PubMed]

157. Hiona, A.; Sanz, A.; Kujoth, G.C.; Pamplona, R.; Seo, A.Y.; Hofer, T.; Someya, S.; Miyakawa, T.; Nakayama, C.; Samhan-Arias, A.K.; et al. Mitochondrial DNA mutations induce mitochondrial dysfunction, apoptosis and sarcopenia in skeletal muscle of mitochondrial DNA mutator mice. PLoS ONE 2010, 5, e11468. [CrossRef]

158. Edgar, D.; Shabalina, I.; Camara, Y.; Wredenberg, A.; Calvaruso, M.A.; Nijtmans, L.; Nedergaard, J.; Cannon, B.; Larsson, N.G.; Trifunovic, A. Random point mutations with major effects on protein-coding genes are the driving force behind premature aging in mtDNA mutator mice. Cell Metab. 2009, 10, 131-138. [CrossRef] 
159. Dai, Y.; Clark, J.; Zheng, K.; Kujoth, G.C.; Prolla, T.A.; Simon, D.K. Somatic mitochondrial DNA mutations do not increase neuronal vulnerability to MPTP in young POLG mutator mice. Neurotoxicol. Teratol. 2014, 46, 62-67. [CrossRef]

160. Hauser, D.N.; Primiani, C.T.; Langston, R.G.; Kumaran, R.; Cookson, M.R. The Polg Mutator Phenotype Does Not Cause Dopaminergic Neurodegeneration in DJ-1-Deficient Mice. eNeuro 2015, 2. [CrossRef]

161. Ahlqvist, K.J.; Hämäläinen, R.H.; Yatsuga, S.; Uutela, M.; Terzioglu, M.; Götz, A.; Forsström, S.; Salven, P.; Angers-Loustau, A.; Kopra, O.H.; et al. Somatic progenitor cell vulnerability to mitochondrial DNA mutagenesis underlies progeroid phenotypes in Polg mutator mice. Cell Metab. 2012, 15, 100-109. [CrossRef] [PubMed]

162. Logan, A.; Shabalina, I.G.; Prime, T.A.; Rogatti, S.; Kalinovich, A.V.; Hartley, R.C.; Budd, R.C.; Cannon, B.; Murphy, M.P. In vivo levels of mitochondrial hydrogen peroxide increase with age in mtDNA mutator mice. Aging Cell 2014, 13, 765-768. [CrossRef] [PubMed]

163. Hauser, D.N.; Dillman, A.A.; Ding, J.; Li, Y.; Cookson, M.R. Post-translational decrease in respiratory chain proteins in the Polg mutator mouse brain. PLoS ONE 2014, 9, e94646. [CrossRef] [PubMed]

164. Chen, C.; Turnbull, D.M.; Reeve, A.K. Mitochondrial Dysfunction in Parkinson's Disease-Cause or Consequence? Biology 2019, 8, 38. [CrossRef]

165. Müller-Nedebock, A.C.; Brennan, R.R.; Venter, M.; Pienaar, I.S.; van der Westhuizen, F.H.; Elson, J.L.; Ross, O.A.; Bardien, S. The unresolved role of mitochondrial DNA in Parkinson's disease: An overview of published studies, their limitations, and future prospects. Neurochem. Int. 2019, 129, 104495. [CrossRef]

166. Lin, X.; Shi, M.; Masilamoni, J.G.; Dator, R.; Movius, J.; Aro, P.; Smith, Y.; Zhang, J. Proteomic profiling in MPTP monkey model for early Parkinson disease biomarker discovery. Biochim. Biophys Acta 2015, 1854, 779-787. [CrossRef]

167. Sharma, L.K.; Lu, J.; Bai, Y. Mitochondrial respiratory complex I: Structure, function and implication in human diseases. Curr Med. Chem. 2009, 16, 1266-1277. [CrossRef]

168. Kirby, D.M.; McFarland, R.; Ohtake, A.; Dunning, C.; Ryan, M.T.; Wilson, C.; Ketteridge, D.; Turnbull, D.M.; Thorburn, D.R.; Taylor, R.W. Mutations of the mitochondrial ND1 gene as a cause of MELAS. J. Med. Genet. 2004, 41, 784-789. [CrossRef]

169. McFarland, R.; Kirby, D.M.; Fowler, K.J.; Ohtake, A.; Ryan, M.T.; Amor, D.J.; Fletcher, J.M.; Dixon, J.W.; Collins, F.A.; Turnbull, D.M.; et al. De novo mutations in the mitochondrial ND3 gene as a cause of infantile mitochondrial encephalopathy and complex I deficiency. Ann. Neurol. 2004, 55, 58-64. [CrossRef]

170. Deng, J.H.; Li, Y.; Park, J.S.; Wu, J.; Hu, P.; Lechleiter, J.; Bai, Y. Nuclear suppression of mitochondrial defects in cells without the ND6 subunit. Mol. Cell. Biol. 2006, 26, 1077-1086. [CrossRef]

171. Das, S.; Ferlito, M.; Kent, O.A.; Fox-Talbot, K.; Wang, R.; Liu, D.; Raghavachari, N.; Yang, Y.; Wheelan, S.J.; Murphy, E.; et al. Nuclear miRNA Regulates the Mitochondrial Genome in the Heart. Circ. Res. 2012, 110, 1596-1603. [CrossRef] [PubMed]

172. Passamonti, M.; Calderone, M.; Delpero, M.; Plazzi, F. Clues of in vivo nuclear gene regulation by mitochondrial short non-coding RNAs. Sci. Rep. 2020, 10, 8219. [CrossRef] [PubMed]

173. Castegna, A.; Iacobazzi, V.; Infantino, V. The mitochondrial side of epigenetics. Physiol. Genom. 2015, 47, 299-307. [CrossRef] [PubMed]

Publisher's Note: MDPI stays neutral with regard to jurisdictional claims in published maps and institutional affiliations.

(C) 2020 by the authors. Licensee MDPI, Basel, Switzerland. This article is an open access article distributed under the terms and conditions of the Creative Commons Attribution (CC BY) license (http://creativecommons.org/licenses/by/4.0/). 